\title{
Recent Progress of Chitosan and Chitosan Derivatives-Based Nanoparticles: Pharmaceutical Perspectives of Oral Insulin Delivery
}

\author{
Salma Seyam ${ }^{\circledR}$, Norsyafikah Asyilla Nordin and Mulham Alfatama* \\ Faculty of Pharmacy, Universiti Sultan Zainal Abidin, Besut Campus, Besut 22200, Terengganu, Malaysia; \\ salma4131@gmail.com (S.S.); asyillanordin@unisza.edu.my (N.A.N.) \\ * Correspondence: mulham@unisza.edu.my or mulham4122@yahoo.com; Tel.: +60-14-2255-604
}

Received: 18 September 2020; Accepted: 10 October 2020; Published: 14 October 2020

\begin{abstract}
Diabetes mellitus is a chronic endocrine disease, affecting more than 400 million people around the world. Patients with poorly controlled blood glucose levels are liable to suffer from life-threatening complications, such as cardiovascular, neuropathy, retinopathy and even premature death. Today, subcutaneous parenteral is still the most common route for insulin therapy. Oral insulin administration is favourable and convenient to the patients. In contrast to injection route, oral insulin delivery mimics the physiological pathway of endogenous insulin secretion. However, oral insulin has poor bioavailability (less than $2 \%$ ) due to the harsh physiological environment through the gastrointestinal tract (GIT). Over the last few decades, many attempts have been made to achieve an effective oral insulin formulation with high bioavailability using insulin encapsulation into nanoparticles as advanced technology. Various natural polymers have been employed to fabricate nanoparticles as a delivery vehicle for insulin oral administration. Chitosan, a natural polymer, is extensively studied due to the attractive properties, such as biodegradability, biocompatibility, bioactivity, nontoxicity and polycationic nature. Numerous studies were conducted to evaluate chitosan and chitosan derivatives-based nanoparticles capabilities for oral insulin delivery. This review highlights strategies that have been applied in the recent five years to fabricate chitosan/chitosan derivatives-based nanoparticles for oral insulin delivery. A summary of the barriers hurdle insulin absorption rendering its low bioavailability such as physical, chemical and enzymatic barriers are highlighted with an emphasis on the most common methods of chitosan nanoparticles preparation. Nanocarriers are able to improve the absorption of insulin through GIT, deliver insulin to the blood circulation and lower blood glucose levels. In spite of some drawbacks encountered in this technology, chitosan and chitosan derivatives-based nanoparticles are greatly promising entities for oral insulin delivery.
\end{abstract}

Keywords: chitosan; oral insulin delivery; nanoparticles; diabetes mellitus; ionic gelation

\section{Introduction}

Diabetes mellitus (DM), one of the major epidemics worldwide of the 21st century, is a chronic disease that developed in about 451 million people in 2017 and this number is anticipated to increase to 693 million by 2045 worldwide [1,2]. To date, subcutaneous injections remain the conventional way to deliver insulin daily. However, this route is associated with several drawbacks including poor patient compliance as a result of needle fears, allergic reactions, pain and hypoglycemic episodes [3]. Oral insulin delivery, on the other hand, has been the research of interest globally for decades. Effective oral insulin dose must survive along the gastrointestinal tract (GIT), cross the mucus layer, transport through the intestinal epithelial cells, enter the liver via portal vein and finally reach 
the systemic circulation [4]. However, mere oral administration of insulin is encountered with enzymatic and physiological barriers that negate insulin absorption through intestinal epithelial cells. Such hurdles render insulin poor oral bioavailability, despite the oral route is the most favourable mode of diabetes management [1].

In order to circumvent the above mentioned challenges, numerous studies have been carried out to develop efficient oral insulin delivery systems where nanotechnology appeared to be a favourable platform. Currently, the application of nanomaterials attracts wider attention in pharmaceutical and biomedical research. Nanoparticulates are defined as entities that are synthesized using nanomaterials that endow unique functionality to the delivery system. The drug content and release profiles of nanosystems are tailorable simply by modulating their starting material composition and physical traits [5]. Generally, nanocarriers can be classified according to their compositional structure into polymeric nanoparticle, lipid-based nanoparticles and inorganic nanoparticle (Figure 1) [6]. In the last two decades, great interest was granted to polymeric and lipid-based nanoparticles over inorganic metal ones for proteins/peptides oral delivery, owing to their biocompatibility and biodegradability, as well as promising clinical outcomes [7,8]. Polymeric nanoparticles being inert and non-immunogenicity, it enables them to escape from endosomal recognition and avoiding of degradation by lysosomes [6]. Moreover, while nanoparticles generally facilitate insulin transportation in the intestine by both transcellular and paracellular pathways, polymeric nanoparticles significantly enhance insulin absorption through paracellular pathway by reversely opening the tight junctions between adjacent cells [9]. Thus, of all the nanoparticle used in drug delivery designs, polymeric nanoparticles have gained great interest. Furthermore, methods of formulation are widely available therefore, the range of applications has been expanding to include variety of hydrophilic and hydrophobic dugs of chemical drug classes and dosage forms $[10,11]$. The smart nanocarriers, synthesized from stimulus-responsive building blocks as part of a polymeric structure, can be controlled to release drugs in response to environmental stimuli such as temperature and $\mathrm{pH}$. In addition, nanocarriers can be decorated with targeting ligand for site-specific drug delivery [12]. Polymeric nanoparticles can be either synthesized from biodegradable synthetic polymers, such as poly(lactide-glycolide) (PLGA) copolymers, polyacrylates, or from natural polymers, such as chitosan, alginate, collagen and albumin. Notable advantages of the natural polymeric-based nanoparticles render them particularly unique due to their abundance in nature, non-toxic with established safety profile and easily modifiable [13].

Among all polysaccharides, chitosan has been the primary interest for many investigators in the designing of oral drug delivery system as a function of its biodegradable, biocompatible, smooth of processing and its digestibility by colonic microbial enzymes to emerge colon-targeted delivery of drugs [14]. Nanoparticles-based chitosan are particularly favourable for the mucosal route due to low toxicity, tunable physiochemical properties and mucoadhesion. There are several methods to formulate chitosan nanoparticles, such as ionic gelation, polyelectrolyte complexation, reverse micellar, emulsion solvent diffusion and electrospraying techniques [15]. Careful selection of nanoparticles composition and method of preparation is essential to meet the objectives of protecting the encapsulant (insulin) and deliver it in a sufficient manner to the blood circulation hence, improve its bioavailability. Thus, the nanoparticle formulator must precisely match the desired chemical and physical attributes of chitosan with reference to the biological environment, with chitosan processing technique [10].

What makes chitosan unique over other polysaccharides for oral drug delivery is its chemical structure that allows specific modifications through modulation in the chitosan amine or hydroxyl functional groups [16]. With regards to pharmaceutical applications, these chemical moieties can be utilised to conjugate drugs directly or via linkers. Abundance of amino groups on the backbone of chitosan would enable any amine related conjugations with other molecules, such as methacrylation [17] and carboxymethylation [18].

This review will discuss how recent developments in chitosan/chitosan derivatives-based nanotechnology have been emerged in a multitude of platforms for safe and efficient delivery of insulin orally for the treatment of DM. 


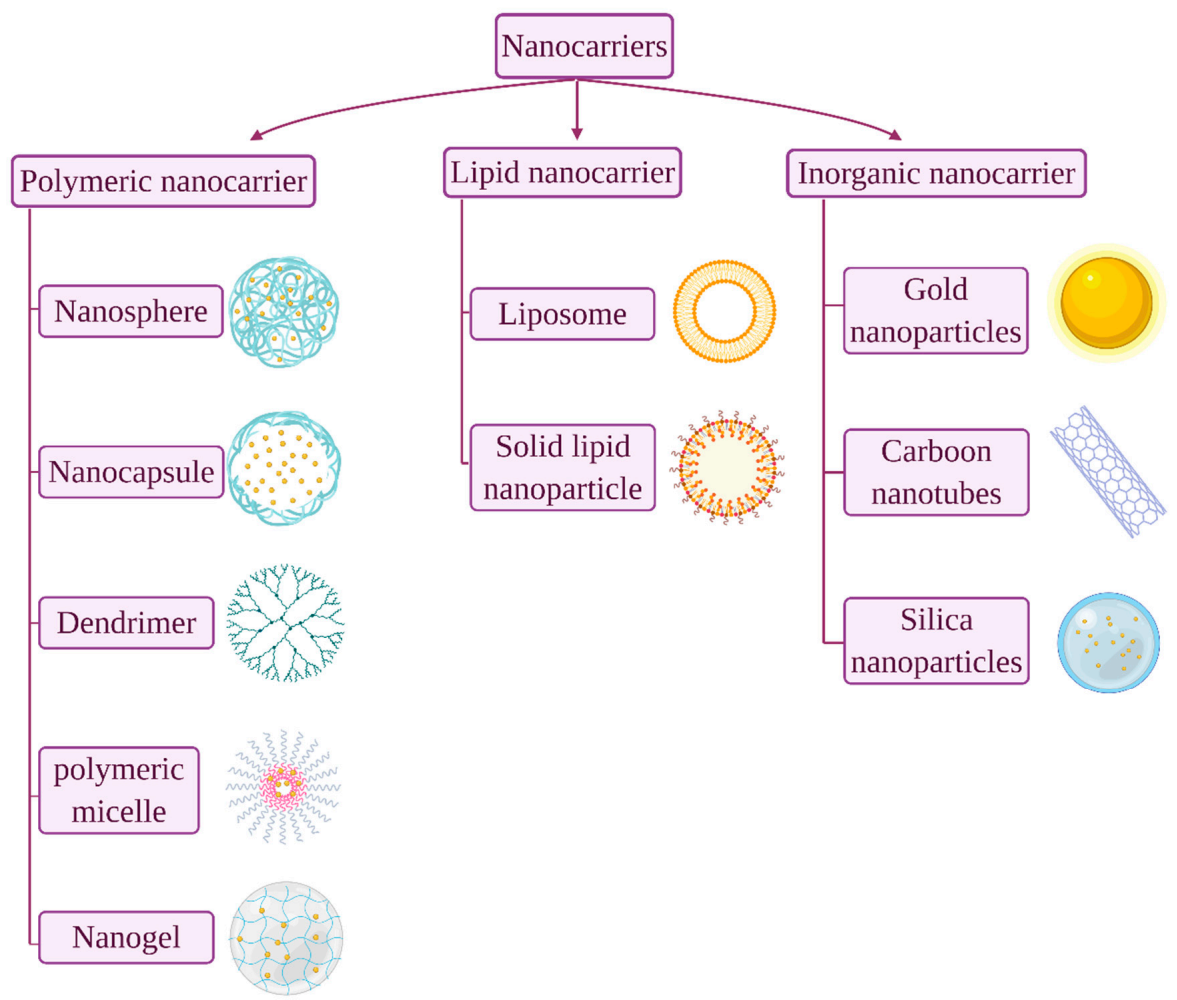

Figure 1. Common nanocarriers used for oral protein/peptide delivery.

\subsection{Diabetes Mellitus}

Diabetes mellitus is a chronic endocrine disease in which an elevation of blood glucose level occurs as a result of reduced or inability of pancreas to produce insulin or due to peripheral tissue uptake defects of insulin [19]. Diabetes can primarily be classified into two types: type 1 diabetes mellitus (T1DM) and type 2 diabetes mellitus (T2DM). In T1DM, the pancreas terminates or reduces insulin production due to pancreatic $\beta$-cell destruction, whereas in T2DM, the cells manifest low sensitivity towards insulin and consequently both types lead to hyperglycemia [20]. Poorly controlled blood glucose levels can bring about serious adverse effects in cardiovascular system, nervous system, retina, and even early death [21,22], hence exogenous insulin intake is imperative in patients with T1DM and advanced T2DM [23].

\subsection{Insulin}

Insulin is an anabolic polypeptide hormone, synthesized in high amounts by islets of Langerhans of pancreatic $\beta$-cells and is responsible to maintain blood glucose level at normal ranges. Proinsulin (an insulin prohormone precursor) is composed of three domains: an amino-terminal B chain, a carboxy-terminal A chain, and a connecting peptide in the middle denoted by C-peptide. By the cleavage of C-peptide, insulin is formed as a quaternary macromolecule composed of two polypeptide chains, A chain (21 amino acid residues) and B chain (30 amino acid residues) that are linked by disulphide bonds (Figure 2) [24]. In 1922, insulin was first successfully isolated by a team of Canadian scientists in Toronto; a discovery that brought about a true medical success and a milestone in the history of treating diabetes [25]. While insulin has been available for treating diabetes for almost a century now, to date, the most common insulin therapy is to be administered to diabetic patients through the parenteral route. Even though this route is still the best route in terms of effectiveness, insulin administered subcutaneously is delivered directly to the peripheral circulation, unmet the endogenous insulin pathway [26]. As a result, insulin enters the liver, which is the main target organ of insulin, at a much lower concentration than normal endogenous insulin which may give rise to 
hyperinsulinemia, weight gain, and hypoglycemic risks [27]. Moreover, injection is invasive and may induce local tissue necrosis, infection, and allergy that in long-term treatment may lead to low patient compliance and serious complications such as, nerve damage, insulin resistance and hypokalemia [28]. Therefore, alternative routes for insulin delivery were widely investigated recently, such as pulmonary, nasal, buccal, transdermal and oral [29].

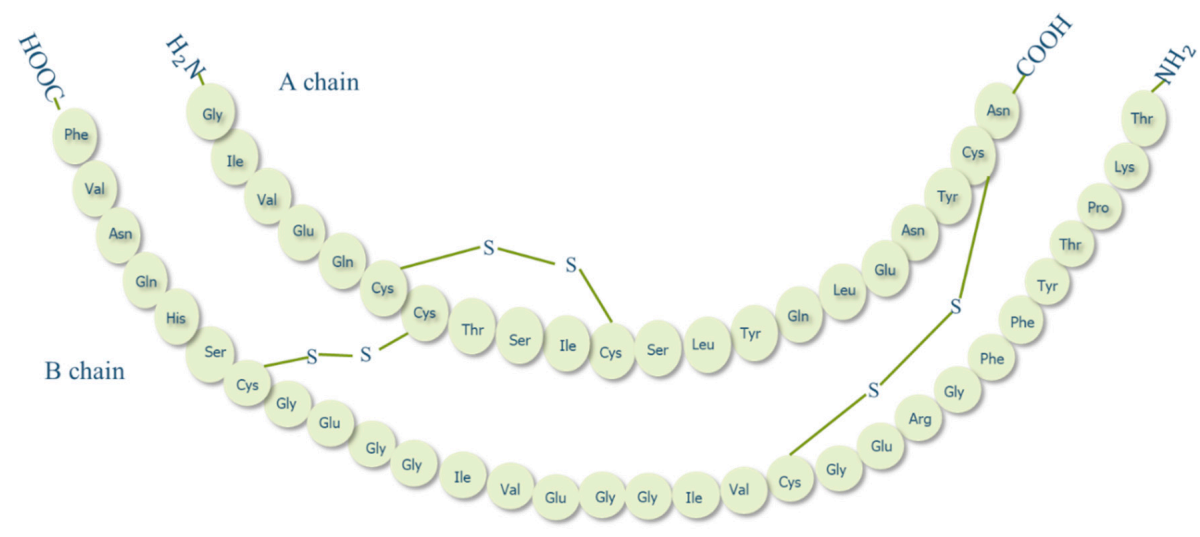

Figure 2. Structure of human insulin.

\subsection{Oral Insulin Delivery}

Among all alternative routes for insulin administration, oral route is the most favourable approach and mimics the endogenous insulin pathway. After oral administration, insulin is absorbed from intestinal lumen and transported via portal circulation to the liver in which the first pass effect takes place, generating a high porto-systemic gradient (Figure 3). Insulin then reaches peripheral circulation at relatively low levels, imitating physiological insulin pathway and avoiding side effects associated with subcutaneous route such as, hypoglycemic episodes and weight gain [30]. However, insulin oral administration is usually characterised by poor bioavailability $(<2 \%)$ [31], due to enzymatic degradation, low stability at different $\mathrm{pHs}$ and low permeability of GIT [32].

1)

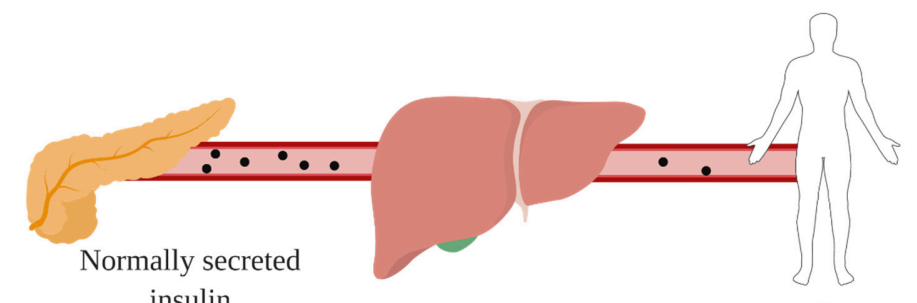
insulin

2)

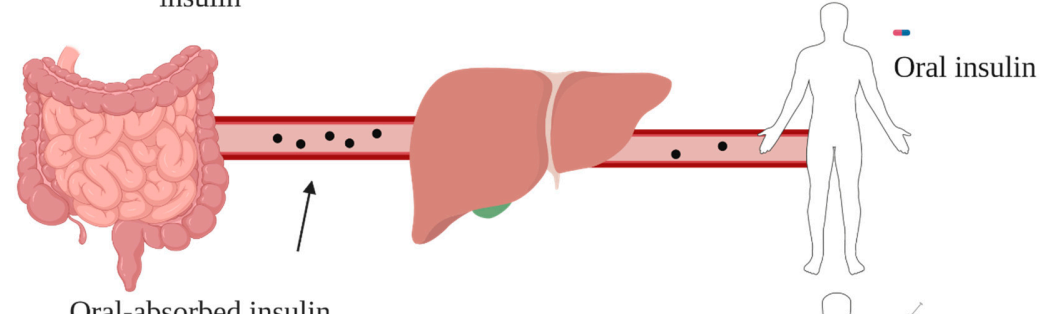

3)

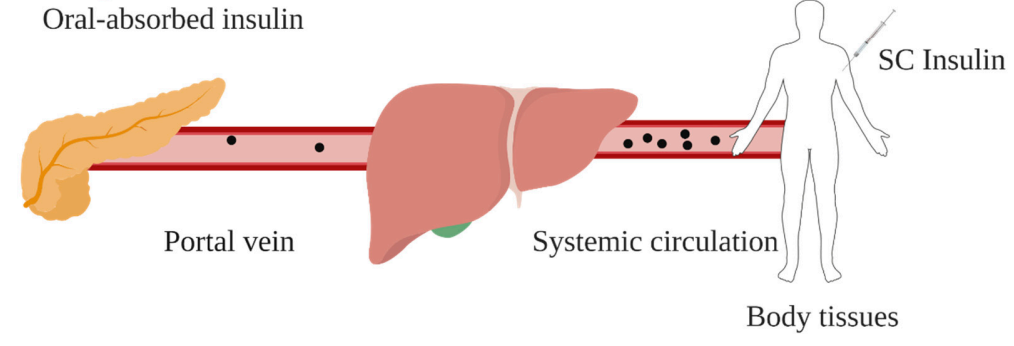

Figure 3. Endogenous insulin pathway under normal physiology (1), orally administered insulin pathway (2) and injected insulin pathway in diabetic patients (3). Created with BioRender.com. 


\subsection{Barriers to Oral Insulin Delivery}

The development of oral insulin delivery system is associated with persistent physiological challenges, where GIT is envisaged to be the main barrier. GIT is responsible for digesting food and selectively absorbing nutrients, electrolytes and fluids. Concurrently, GIT confers a protective barrier against toxic materials such as peptides, viruses and bacteria [33]. These functions are accomplished by a layer of neighboring absorptive and secretory cells, tight junctions that narrowing the paracellular spaces between epithelial cells, a viscous layer of mucus, different $\mathrm{pH}$ conditions along GIT and the presence of enzymes involved in food digestion [34]. Table 1 represents a summary of these conditions or barriers that hinder oral delivery of insulin and limit its bioavailability.

Table 1. Effects of different barriers in gastrointestinal tract (GIT) against insulin oral delivery.

\begin{tabular}{|c|c|c|c|c|}
\hline \multicolumn{5}{|c|}{ Barriers Against Oral Insulin Administration } \\
\hline & Physical Barriers & & Chemical Barriers & Enzymatic Barriers \\
\hline Mucus layer & $\begin{array}{c}\text { Epithelial layer } \\
\text { (Trans-cellular transportation) }\end{array}$ & $\begin{array}{c}\text { Tight junctions } \\
\text { (Para-cellular transportation) }\end{array}$ & \multirow[b]{2}{*}{$\begin{array}{c}\text { Stomach:highly acidic } \\
\text { (pH 1-3.7) } \\
\downarrow \\
\text { Denaturation and } \\
\text { degradation of insulin. } \\
\text { Intestine:neutral and } \\
\text { slightly alkaline (pH 6-8). }\end{array}$} & \multirow[b]{2}{*}{$\begin{array}{l}\text { Insulin breakdowns by the protease's } \\
\text { enzymes found in the GIT [24]. } \\
\text { Stomach: pepsin. } \\
\text { Intestine: mainly trypsin, chymotrypsin }\end{array}$} \\
\hline $\begin{array}{c}\text { Viscous, hydrophilic, } \\
\text { negatively } \\
\text { charged layer } \\
\downarrow \\
\text { Permitting only } \\
\text { hydrophilic net-neutral } \\
\text { molecules to pass } \\
\downarrow\end{array}$ & $\begin{array}{l}\text { Highly limited to lipophilic } \\
\text { drugs with molecular } \\
\text { weight less than } 700 \mathrm{Da} \text { as } \\
\text { the membrane is mainly } \\
\text { consisting of phospholipid } \\
\text { bilayers [30]. }\end{array}$ & $\begin{array}{l}\text { Regulate the transportation } \\
\text { of molecules in between the } \\
\text { epithelial cells. }\end{array}$ & & \\
\hline $\begin{array}{l}\text { Hydrophobic drugs } \\
\text { and proteins are unable } \\
\text { to cross, while cationic } \\
\text { compounds exhibit } \\
\text { low diffusion rate than } \\
\text { neutral ones }[31,35] \text {. }\end{array}$ & $\begin{array}{c}\text { Insulin is hydrophilic } \\
\text { protein with high molecular } \\
\text { weight } 5800 \text { Da. }\end{array}$ & $\begin{array}{l}\text { Selectively permeable to } \\
\text { small hydrophilic } \\
\text { molecules }[30,34,36]\end{array}$ & $\begin{array}{l}\text { This variation in } \mathrm{pH} \\
\text { values may cause } \\
\text { pH-induced oxidation } \\
\text { and deamination of the } \\
\text { protein }[37,38] .\end{array}$ & $\begin{array}{l}\text { cytosolic and membrane-bound } \\
\text { enzymes in the microvilli of intestinal } \\
\text { enterocytes }[39,40] .\end{array}$ \\
\hline
\end{tabular}

\subsection{Chitosan}

Chitosan and chitin have received immense attention in different fields in both research and industrial areas, not only because of their biocompatibility, biodegradability and non-toxic properties, but also because they are readily available, inexpensive and environment-friendly biopolymers [41]. Chitin, the second next to cellulose known as the most abundant natural polysaccharides, is a linear polymer comprises of 1-1,4-linked N-acetyl-D-glucosamine, found in the exoskeleton of insects and crustaceans like crab and shrimp, as well as cell walls of fungi [38]. Chitin can be found in diverse degrees of acetylation, in which the degree of acetylation (DA) equals $50 \%$ or lower, chitin becomes soluble in acidic aqueous solution and is called chitosan [42]. Chitosan, which is the most valuable derivative of chitin, can be obtained by three different chitin-deacetylation methods: chemical alkaline, microbial and enzyme-based method [43]. Structurally, chitosan is a linear polymer composed of randomly distributed $\beta 1-4$ linked D-glucosamine and $\mathrm{N}$-acetyl D-glucosamine units, with one amino group $\left(\mathrm{NH}_{2}\right)$ at $\mathrm{C}-2$, and two hydroxyl $(\mathrm{OH})$ groups at $\mathrm{C}-3$ and $\mathrm{C}-6$ in each repeating glycosidic units (Figure 4) $[44,45]$.

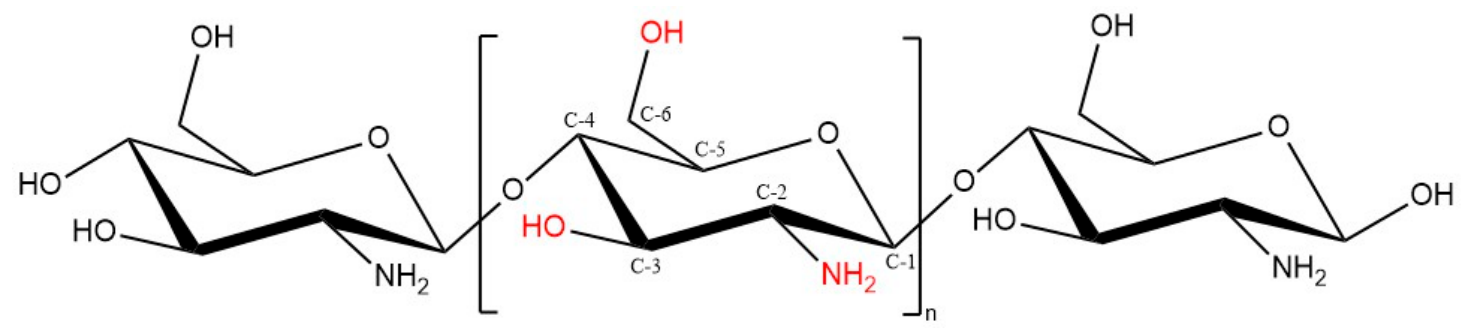

Figure 4. Chitosan chemical structure (DD $\geq 50 \%)$.

Chitosan has received widespread interest to deliver therapeutics for different diseases due to its unique attributes including biocompatibility, biodegradability, mucoadhesion, 
absorption-enhancing effect, low immune reactions, simplicity of functional groups grafting and non-toxicity [46]. Chitosan also possesses diverse biological activities, such as antioxidant [47], antimicrobial [48], anticancer [49] and wound healing propensity [50]. This advocates the intensive research studies of chitosan and its derivatives for various pharmaceutical and medical applications including tissue engineering [51], food technology [52], wound healing [50], gene delivery [53] and textile industry [54]. Besides, it has also been widely employed in various forms in drug delivery systems such as tablets [55], microspheres [56], nanoparticles [57], nanofibers [58], beads [59], films [60], hydrogels [61], conjugates [62] and chitosan-based nanocomposites [63].

Chitosan has an essential polycationic property ascribing to its $\mathrm{pKa}$ value of 6.5; in acidic solutions the amino groups $\left(\mathrm{NH}_{2}\right)$ on the backbone of chitosan get protonated and become positively charged $\left(\mathrm{NH}_{3}{ }^{+}\right)$making chitosan soluble in aqueous acidic solutions; whereas in an alkaline environment, the amino groups lose their positive charges and chitosan renders insoluble [64]. The physiochemical properties of chitosan including viscosity, solubility, adsorption on solids, elasticity, tear strength and biofunctional propensity are greatly attributed to the molecular weight (MW) and degree of deacetylation (DD). The average MW and DD of chitosan may range from 50 to over $2000 \mathrm{kD}$, and from $30 \%$ to $95 \%$, respectively, depending on the source of chitosan and its preparation method from chitin. Other processing conditions may also alter the physical characteristics and performance of the final chitosan product, such as the type and concentration of reagents, time and temperature used throughout the synthesis process $[63,65]$. Despite of all the functional properties, chitosan poor solubility hinders its applicability as a result of uneven distribution of acetyl groups and aggregates [66]. This intervenes with the biomedical avails of chitosan, especially at near physiological $\mathrm{pH}$ 7.4, where chitosan is insoluble and less effective as an absorption enhancing agent [65,67]. Hence, it is imperative to modulate chitosan solubility via introducing various derivatives to maximise its applications especially in drug design and drug delivery, such as chitosan-based nanoparticles.

\subsection{Chitosan Nanoparticles}

Nanoparticles are defined as entities with the size range from 10 to $999 \mathrm{~nm}$. Different types of insulin-loaded nanoparticles for oral delivery administration have been formulated using various materials such as lipids, metals, proteins, natural polymers and synthetic polymers, either alone or combined [68]. Nanoparticles are advantageous due to their small size, large surface area to volume ratio by which their retention time to reach the intestinal absorption sites are prolonged, thus improved permeation and bioavailability. This in turn reduces the frequency and doses of encapsulant and enhances patient compliance [69].

Over the last few decades, different natural polymers have been adopted to ease the limitations associated with oral insulin absorption exploiting advanced nanotechnology. Chitosan and its derivatives are considered as an excellent choice and have been widely investigated in oral insulin designs. The involvement of chitosan as insulin carrier is based on the mucoadhesive property and its ability to reversibly open the tight junctions of epithelial cells. These properties are mainly attributed to the positive moieties possessed by chitosan surface amine groups [70].

Nanoparticles prepared from chitosan and/or chitosan derivatives generally possess a positively charged surface. Chitosan can be tailored to meet a specific goal owing to its unique functional groups, making it a polymer with a formidable range of potential applications [10]. Chitosan nanoparticles can be synthesised using different methods including ionic gelation, emulsion solvent diffusion, emulsion-droplet coalescence, polyelectrolyte complexation, reverse micelle formation, complex coacervation or solvent evaporation methods.

\section{Preparation Methods of Chitosan Nanoparticles}

Chitosan nanoparticles have been documented in the literature as a potential carrier for various drug delivery. A summary of the most common preparation methods of chitosan nanoparticles is outlined below. 


\subsection{Ionic Gelation}

Ionic gelation method was first reported by Calvo et al. [71]. Firstly, chitosan and anionic crosslinker solutions are prepared by dissolving chitosan in diluted acetic acid, while an anionic crosslinker such as sodium tripolyphosphate (TPP) is dissolved in distilled water. Then, ionic gelation takes place by adding TPP solution dropwise into the cationic solution of chitosan under mechanical stirring at room temperature. Nanoparticle will be instantly formed as a result of the complexation between TPP as a negatively charged polyanion, and the positively charged amine group of chitosan by electrostatic forces (Figure 5) [72]. The advantages of this technique include, simple and easy of preparation, organic solvent-free, and can be done under mild conditions, while the possible disadvantage is the relatively higher polydispersity index of the prepared nanoparticles.

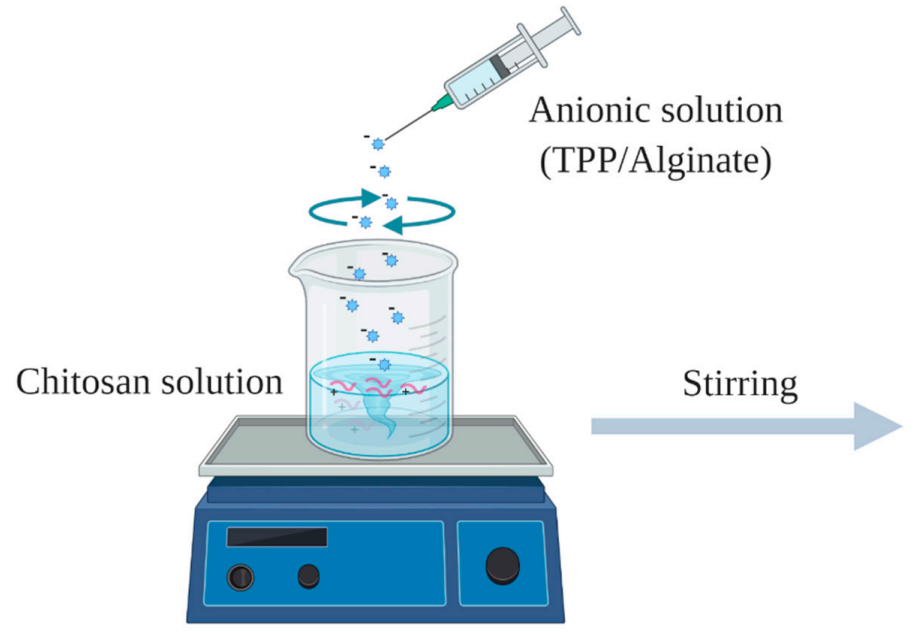

Magnetic stirrer

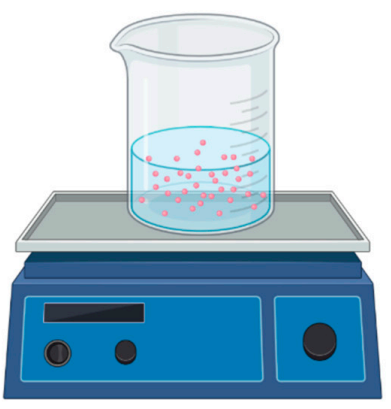

Spontaneously formed chitosan nanoparticles

Figure 5. Schematic diagram of chitosan nanoparticles prepared via ionic gelation/polyelectrolyte complexation.

\subsection{Polyelectrolyte Complex (PEC)}

Polyelectrolyte complexes are formed by self-assembly of the positively charged chitosan and negatively charged polyelectrolyte macromolecules such as dextran sulphate, alginate, hyaluronic acid and DNA. Nanoparticles will be spontaneously formed upon addition of anionic solution into acetic acid solution of chitosan, under mechanical stirring at room temperature (Figure 5). The advantages of this method are similar to those of ionic gelation technique, however, optimisation of the ratio between oppositely polyelectrolytes is challenging.

\subsection{Reverse Micellar Method}

This method was described by Brunel et al. [73], where the formation of the nanoparticles takes place in an aqueous core of a reverse micellar droplets, followed by cross-linking with glutaraldehyde [74]. Formation of reverse micelles is aided by adding surfactant to the organic solvent, while chitosan-drug aqueous solution with glutaraldehyde as crosslinker should be added with continues stirring to avoid turbidity. In order to attain complete cross-linkage for chitosan, it is advised to maintain the stirring overnight. Then, the organic solvent is evaporated, and the yield nanoparticles can be harvested by precipitation with a suitable salt (Figure 6) [75]. The advantages of this method are associated with the ability of production of small particle size with a narrow size of distribution [76], while the disadvantages including the laborious and time-consuming process and the presence of organic solvent and surfactant. 


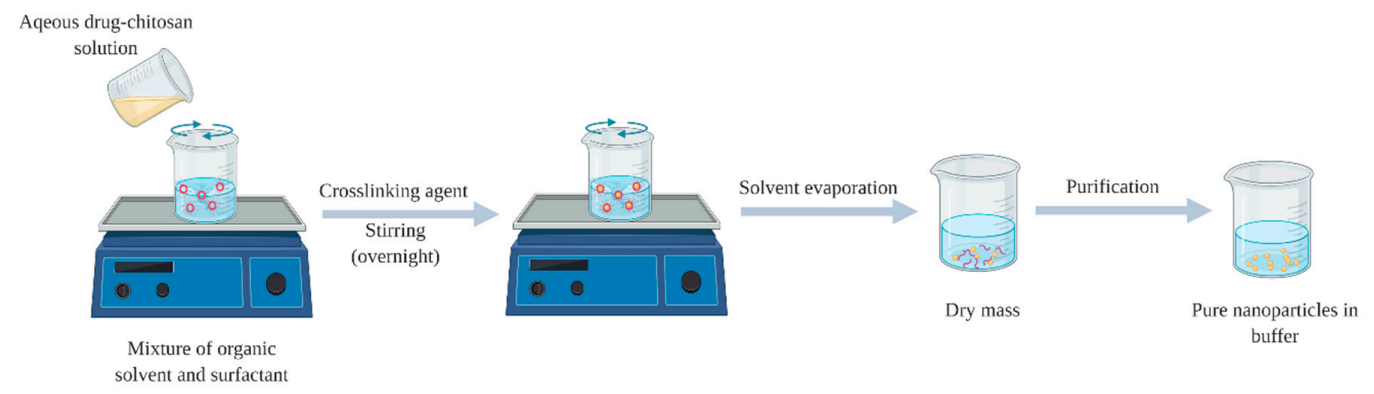

Figure 6. Schematic diagram of chitosan nanoparticles prepared via reverse micellar method.

\subsection{Emulsion Solvent Diffusion}

This method was first reported by El-Shabouri et al., with principle of partial miscibility of organic solvent as an oil phase with water [77]. Oil-in-water $(\mathrm{o} / \mathrm{w})$ emulsion is prepared by pouring organic phase such as methylene chloride or acetone solution of hydrophobic drug into chitosan aqueous solution that contains stabilizer (poloxamer or lecithin) under continuous stirring. Under intense homogenization, the emulsion has to be diluted with a large amount of water to promote a complete diffusion of organic solvent into aqueous phase, overcoming the organic solvent miscibility in water. Finally, nanoparticles are formed by means of polymer (chitosan) precipitation as a result of reduced chitosan solubility as acetone diffuses into the aqueous phase (Figure 7) $[75,78]$. The advantages of the method are the feasibility to scale up and suitability for hydrophobic drugs encapsulation, while the possible disadvantages can be the use of organic solvent, surfactant and high shear force (vortex).
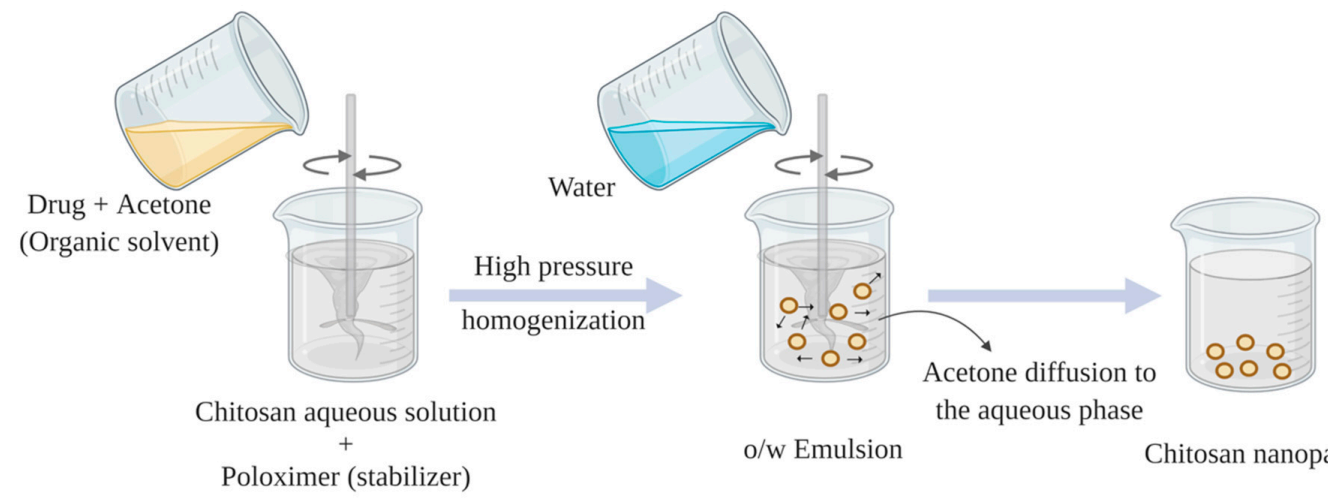

Figure 7. Schematic diagram of chitosan nanoparticles prepared via emulsion solvent diffusion.

\subsection{Electrospraying Technique}

Among various reported nanoparticle preparation methods, electrospraying has been established as a promising and appreciable approach. Principally, it is an electrohydrodynamic processes used in the formation of nanoparticles [79]. To produce nanoparticles by electrospraying approach, high voltage electric field is applied into the polymeric solution flowing out of the nozzle in order to break it down to very fine nano-sized droplets possessing the same charge which assists their dispersion and prevents possible coagulation $[80,81]$. The droplet size and morphology can be tuned by altering specific variables that can be classified into the process related parameter, such as applied electric voltage, solution flow rate, distance between needle tip and collector and the type of collector. Additionally, material-related parameters are: type of polymer, its MW and concentration, as well as excipients used [82]. Chitosan nanoparticles have been recently fabricated using electrospraying technique, exhibited unique features that may have wide applications in pharmaceutical and biomedical fields (Figure 8) [83-86]. The advantages of this method can be summarised by its simple and one step technique, high MW polymers can be used, monodispersed nanoparticles can be obtained and low cost [87], however, the disadvantage is associated with the low yield product. 


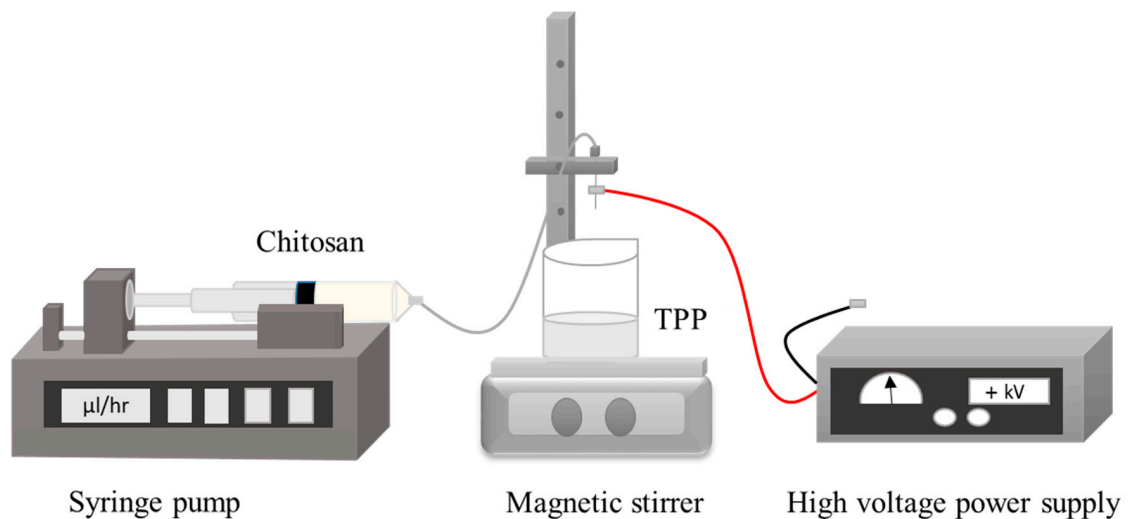

Figure 8. Schematic diagram of chitosan nanoparticles prepared via electrospray technique.

\section{Insulin-Loaded Chitosan Nanoparticles}

Chitosan nanoparticles have been widely used to encapsulate insulin mainly via ionic gelation and polyelectrolyte complexation methods. This is attributed to their simplicity, and ability to produce nanoparticles under mild conditions where heat, organic solvent, or toxic cross-linking stabilizer agents are negated. Moreover, the prepared nanoparticles possess narrow size distribution $[67,88]$. Both ionic gelation and polyelectrolyte complexation are classified as electrostatic complexation method mainly based on the cationic nature of chitosan mediated by protonation of its amine groups in acidic medium [67]. When protonation degree of chitosan chains is adequate, it enables reactions with anionic molecules, providing excellent gel-forming properties that impart a unique opportunity for insulin entrapment [89]. The main difference between the two methods is the nature of the anionic molecules. Ionic chitosan gelation is mediated by small anionic molecules, such as phosphate, citrate, sulphate, while polyelectrolyte complexation is achieved by anionic macromolecules such as dextran sulphate, alginate, hyaluronic acid and DNA $[88,90]$. The latter approach is often referred to as interfacial coacervation or complex coacervation. One of the most studied polyanion with chitosan is alginate, which is a non-toxic, biocompatible and biodegradable, mucoadhesive and non-immunogenic anionic polymer (Figure 9) [91].

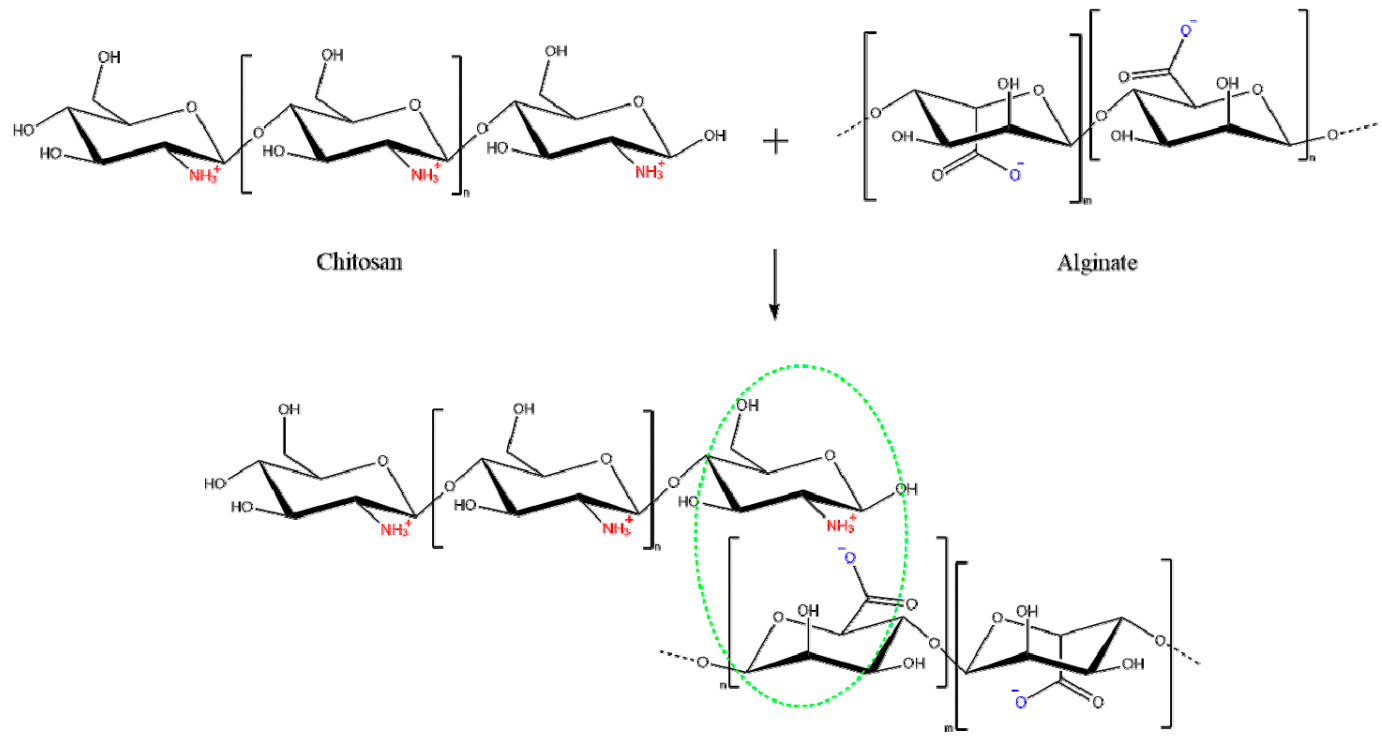

Polyelectrolyte complex

Figure 9. Schematic representation of the interaction between alginate as a polyanion and chitosan as polycation: mixing of the oppositely charged polyelectrolytes leads to formation of a polyelectrolyte complex caused by the electrostatic interactions between the ions. 
Chitosan-alginate polyelectrolyte complexation can be enabled via three main approaches: ionotropic pre-gelation of alginate with calcium chloride $\left(\mathrm{CaCl}_{2}\right)$ or any divalent ions followed by complexation, mixing diluted solutions of chitosan and alginate to acquire a plain complex coacervation, or oil-in-water $(\mathrm{o} / \mathrm{w})$ microemulsion of alginate followed by further complexation with chitosan [92]. Mukhopadhyay et al., have managed to prepare insulin-loaded core/shell chitosan-alginate nanoparticles using the first approach by admixing dropwise insulin in $0.1 \mathrm{M} \mathrm{HCl}$ and $\mathrm{CaCl}_{2}$ to the prepared alginate solution, forming ionic polyelectrolytes after appropriate sonication. This step was followed by chitosan polyelectrolyte complexation by adding chitosan solution with mild stirring to form core-shell nanoparticles via electrostatic interactions. The prepared nanoparticles were characterised by small particle size of 100-200 nm, high encapsulation efficiency of $\sim 85 \%$ and $\mathrm{pH}$-responsive sustained release of insulin. The oral administration of insulin-loaded nanoparticles at a dose of $100 \mathrm{IU} / \mathrm{kg}$ in the in vivo study exhibited a maximum serum insulin concentration at the 7th $\mathrm{h}$ of administration, advocating the nanoparticle's ability to cross intestinal epithelium and protects insulin from enzymatic degradation in GIT. The results showed that the nanoformulation conferred significantly higher bioavailability $(8.11 \%)$ than mere oral administration of insulin. Hepatotoxicity test to evaluate any possible toxicity of the nanoparticles by measuring liver-specific enzymes; alanine aminotransferase (ALAT) and aspartate aminotransferase (ASAT), has reported that neither liver was damaged nor the liver function was disrupted, demonstrating the safety of the prepared nanoparticles after oral administration [93]. Bhattacharyya et al., have applied similar preparation method as above to form core-shell nanocarrier for oral insulin delivery. In their study, instead of using mere alginate, a homogenous blend of polyurethane, a biodegradable and biocompatible synthetic polymer, with alginate (PU-Alg) was utilised to synthesise the core of the desired nanoparticles. The nanoparticles were formulated by adding a mixture solution of insulin and $\mathrm{CaCl}_{2}$ dropwise to PU-Alg blend solution while maintaining sonication for 15 min to allow the construction of the nanoparticle core. Then chitosan solution was added and sonicated for another $15 \mathrm{~min}$ to prepare PU-Alg core and chitosan shell nanoparticles. The prepared nanoparticles exhibited small particle size $90-100 \mathrm{~nm}$, more than $90 \%$ encapsulation efficiency, prolonged blood glucose lowering in diabetic mice (up to $98 \mathrm{mg} / \mathrm{dL}$ for the insulin dose of $100 \mathrm{IU} / \mathrm{kg}$ at the 10th h), and relatively improved insulin bioavailability (10.36\%) [94]. Polyelectrolyte complex of chitosan and alginate has been used by Chen et al., to develop a modified system as a second step after preparing insulin-loaded nanoparticles by double emulsion $\mathrm{w} / \mathrm{o} / \mathrm{w}$ solvent evaporation method. Insulin-loaded $\mathrm{w} / \mathrm{o} / \mathrm{w}$ nanoemulsion of coated chitosan and alginate were firstly prepared, then mixed together for further coacervation of polyelectrolyte complexes as an efficient oral insulin delivery vehicle (Figure 10). The encapsulation efficiency of the obtained alginate-coated and chitosan-coated nanoparticles were $81.5 \pm 7.4 \%$ and $55.2 \pm 7.0 \%$, respectively and average particle size range 200-300 nm. The polyelectrolyte complex exhibited a relative bioavailability of $7.51 \%$, non-cytotoxicity against Caco-2 cell, $\mathrm{pH}$ responsive propensity and controlled release profiles (sustained release at $\mathrm{pH}$ 6.8, while protecting the drug at $\mathrm{pH}$ 1.2) [95]. It could be concluded that additional polyelectrolyte complex step has brought about significant improvement on blood glucose lowering propensity by 3 -folds for a duration up to $12 \mathrm{~h}$ compared to polyelectrolyte complex-free formulation as a result of modulating insulin release throughout the GIT.

In another study, low MW PEG (5 kDa) was conjugated with anionic polymer chondroitin sulfate and self-assembled with the cationic chitosan to render negatively charged insulin nanoparticles. In this study, Pereira De Sousa et al., aimed to prepare highly mucus-permeating nanoparticles by combining two different strategies namely, the virus-mimicking and surface PEGylation approaches. Despite of relatively large particle size $(510-670 \mathrm{~nm})$ obtained, the nanoparticles exhibited five-fold higher as mucus permeation enhancer as compared to non-PEGylated ones [96].

Recent study has utilised Dz13Scr, an anionic oligonucleotide with excellent biocompatibility and minimal cytotoxicity with chitosan to formulate insulin nanoparticles via complex coacervation technique. The developed nanoparticles showed acceptable size range (479 $\pm 24 \mathrm{~nm})$, 
uniform polydispersity index (PDI $0.34 \pm 0.06)$ and improved encapsulation efficiency $(88.71 \pm 0.3 \%)$. It was envisaged that this formulation is a potential oral insulin delivery system as it demonstrated improved stability in acidic condition mimicking those in the stomach with only $13 \%$ insulin release, while in alkaline medium, a biphasic release pattern of initial burst release (49.49\%) followed by a sustained release propensity ( $88 \%$ ) in $10 \mathrm{~h}$ was attainable. Moreover, the physiochemical properties of the prepared nanoparticles remained stable after being stored for two months at $4{ }^{\circ} \mathrm{C}$ as compared to newly-synthesised formulations. The developed nanoparticles achieved a balance between the mucoadhesive property caused by the cationic chitosan and the mucopenetrating capacity attributed to hydrophilic Dz13Scr presence. As a result, the encapsulated insulin was able to permeate across the GI cells (approximately $68 \%$ of encapsulated insulin translocated to the basolateral chambers within $1 \mathrm{~h}$ ) and induces glucose consumption; as it demonstrated comparable effect in promoting the glucose uptake from $16.98 \%$ when native insulin used to $20.79 \%$ of glucose uptake in C2C12 cells by $12 \mathrm{~h}$ of treatment [97].

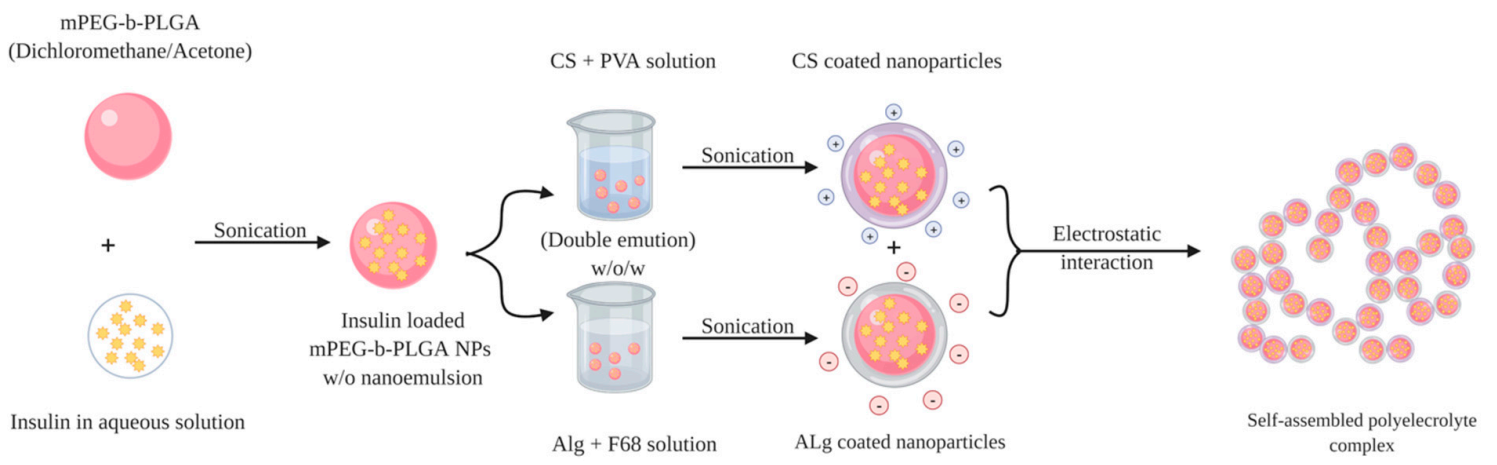

Figure 10. Schematic representation of the double emulsion method used to prepare insulin-loaded polyelectrolyte complexes. Positively charged chitosan nanoparticles (CSNPs) and negatively charged alginate nanoparticles (AlgNPs) are prepared, respectively, then two kinds of nanoparticles are mixed together to self-assemble forming polyelectrolyte complexes by electrostatic interaction.

Recently, modified hybrid systems were developed to merge the conventional ionotropic gelation of chitosan with other preparation methods or strategies to obtain the most out of the prepared nanoparticles in terms of preferable characteristics, such as enhanced bioavailability of encapsulant and improved stability along GIT. Erel G et al., have designed insulin-loaded chitosan nanoparticles initially by ionic gelation between chitosan and TPP. As a novel approach, the nanoparticles were then loaded into the inner phase of prepared w/o microemulsion to grant controlled release property, enhance in vivo stability and promote drug absorption in the GIT. The effect of incorporating insulin into chitosan nanoparticle had a significant protective effect. After $8 \mathrm{~h}$ of administration of insulin-loaded chitosan nanoparticles embedded in microemulsion, the blood glucose level reduced by $33.6 \%$ of the initial blood glucose level, compared to only $17 \%$ reduction in the case of nanoparticles-free microemulsion [98].

Another new method was developed by He et al., also depends on the electrostatic interaction between chitosan and TPP to prepare size-controlled chitosan nanoparticles for oral insulin delivery called flash nanocomplexation (FNC). In this method, a multi-inlet vortex mixer was used to infuse aqueous solutions of chitosan, TPP and insulin to assure an efficient and rapid mixing to fabricate highly uniform insulin-loaded nanoparticles. This method enables advantage of continuous production of nanoparticles with controlled and reducible particle size $(45 \mathrm{~nm})$ while maintaining high encapsulation efficiency $(90 \%)$, compared with the ordinary dropwise method at $92 \pm 8.4 \mathrm{~nm}$ and $62.3 \pm 4.9 \%$ for particle size and encapsulation efficiency, respectively [99].

Incorporating chitosan-insulin polyelectrolyte complex (CS-Ins-PEC) with lecithin liposomes to formulate chitosan/lithin liposomal nanovesicles was investigated by Al-Remawi et al., as a possible 
carrier for insulin oral delivery. Insulin was first reacted with chitosan to form Ins-CS PEC, then the PEC was added to the negatively charged liposomal dispersion developing Ins-CS PEC-associated lecithin liposomes. The optimal formulation possessed high net zeta potential around $-30 \mathrm{mV}$ and small particle size of $105 \mathrm{~nm} \pm 17 \mathrm{~nm}$ when the ratios of Ins-Cs complex to lecithin was 9\% (v/v). The encapsulation efficiency was slightly improved due to the presence of chitosan to interact with insulin comparable to similar chitosan-free formulations [100]. For in vivo study, blood glucose lowering effect was observed after $2 \mathrm{~h}$ of oral administration accompanied with a prolonged effect up to $8 \mathrm{~h}$. However, the effect was modest that can be attributed to the relatively poor association efficiency [101]. Table 2 represents the most recent examples of the compositions, method of preparations and attributes of insulin loaded chitosan-based nanoparticles. 
Table 2. Examples of chitosan-based nanoparticles-loaded insulin.

\begin{tabular}{|c|c|c|c|c|c|c|c|c|}
\hline Nanocarrier & Preparation Method & Particle Size $(\mathrm{nm})$ & Zeta Potential (mV) & Entrapment Efficiency (\%) & In Vitro Insulin Release & Dose (IU/kg) & In Vivo Observation & Reference \\
\hline $\begin{array}{c}\text { Chitosan (CS) } \\
\text { MW }(25-65 \mathrm{kDa}) \\
83-86 \% \\
\text { Deacetylation Degree(DD) } \\
+ \\
\text { Alginate }(\mathrm{ALG}) \\
\text { MW }(1.03 \times 105 \mathrm{~g} / \mathrm{mol}) \\
\end{array}$ & Polyelectrolyte complexation & 216 & +3.89 & 78.3 & $\begin{array}{c}\text { A burst release with max. } \\
\text { of } 26.7 \% \text { of insulin release } \\
\text { was found in } \mathrm{pH} 1.2, \\
\text { followed by a sustained } \\
\text { and prolonged insulin } \\
\text { release }(79-84 \%) \text { through } \\
24 \mathrm{~h} .\end{array}$ & $\begin{array}{l}\text { Oral: } \\
50-100 \\
\text { SC: } \\
5\end{array}$ & $\begin{array}{l}\text { Insulin-loaded CS/ALG } \\
\mathrm{NPs}(50 \text { and } 100 \mathrm{IU} / \mathrm{kg} \text { ) } \\
\text { showed reduction in the } \\
\text { blood glucose level to } 143 \\
\text { and } 104 \mathrm{mg} / \mathrm{dL}, \\
\text { respectively, with sustained } \\
\text { effect up to } 9 \mathrm{~h} \text {. }\end{array}$ & [93] \\
\hline $\begin{array}{c}\text { Medium MW, } 75 \%, 85 \% \\
\text { deacetylated Chitosan } \\
+ \\
\text { TPP } \\
\text { ratio } 6: 1\end{array}$ & Ionic gelation method & $\begin{array}{c}\text { Nanoparticle } \\
356.5 \pm 43.4 \\
\text { (Microemultion) } \\
99.1 \pm 28.7\end{array}$ & $\begin{array}{c}\text { Nanoparticle } \\
46.5 \\
\text { (Microemultion) } \\
13.1\end{array}$ & - & $\begin{array}{c}\text { At } \mathrm{pH} 2.5 \text { after } 2 \mathrm{~h}, \\
\text { insulin release } \\
\text { from microemulsion } \\
\text { was } 48.1 \% \text {. } \\
\text { At } \mathrm{pH} 6.8 \text { after } 2 \mathrm{~h} \text {, } \\
\text { the release was } 51.2 \% \text { and } \\
\text { after } 3 \mathrm{~h} \text { it was } 66.1 \% \text {. }\end{array}$ & $\begin{array}{l}\text { Oral: } \\
50 \\
\text { SC: } \\
1\end{array}$ & $\begin{array}{l}\text { Plasma glucose level } \\
\text { reduced to } 88.7 \% \text { after } 3 \mathrm{~h} \\
\text { and it maintained } \\
\text { at } 66.4 \% \text { of the initial } \\
\text { blood glucose level } \\
\text { after } 8 \mathrm{~h} .\end{array}$ & [98] \\
\hline $\begin{array}{c}\text { Chitosan } 25 \mathrm{kDa}, \\
+ \\
\text { Chondroitin sulphate } \\
\text { (ChS) 20-30 KDa } \\
+ \\
\text { Polyethylene glycol } 5000 \mathrm{Da} \\
\text { (PEG) }\end{array}$ & Ionic gelation & $510-670$ & -1 to -5 & $2.18 \pm 0.70$ & $\begin{array}{l}\text { In simulated intestinal } \\
\text { fluid (SIF) buffer, } \\
\text { insulin release profile } \\
\text { showed a gradual release } \\
\text { of the protein reaching } \\
65 \% \text { in } 4 \mathrm{~h} \text {, followed by } \\
\text { a plateau. }\end{array}$ & - & - & [96] \\
\hline $\begin{array}{c}90 \mathrm{KDa} \mathrm{MW,} \\
85 \% \text { deacetylated chitosan } \\
+ \\
\text { TPP }\end{array}$ & $\begin{array}{l}\text { Flash nanocomplexation using } \\
\text { multi-inlet vortex mixer }\end{array}$ & $46.2 \pm 2.7$ & $9.4 \pm 1.2$ & $91.0 \pm 1.7$ & $\begin{array}{c}\text { The amount of released } \\
\text { insulin at } \mathrm{pH} 2.5 \text { was } \\
\text { about } 16 \% \text {, } \\
\text { while negligible amount } \\
\text { at pH 6.6, and a sustained } \\
\text { release of insulin within } \\
\text { a few hours at } \mathrm{pH} 7.4\end{array}$ & $\begin{array}{l}\text { Oral: } \\
60 \text { or } 120 \\
\text { SC: } \\
10\end{array}$ & $\begin{array}{c}\text { Gradual but distinct } \\
\text { reduction of blood } \\
\text { glucose levels by } 51 \% \\
(60 \mathrm{IU} / \mathrm{kg}) \text { and } 59 \% \\
(120 \mathrm{IU} / \mathrm{kg}) \text { within } 8 \mathrm{~h} .\end{array}$ & [99] \\
\hline $\begin{array}{c}\text { Chitosan } \\
(28 \mathrm{kDa}) \\
+ \\
\text { Lecithin liposomes } \\
+ \\
\text { L-Arginine }\end{array}$ & $\begin{array}{l}\text { CS-insulin dispersion } \\
\text { (polyelectrolyte complexation) } \\
\text { added to lecithin } \\
\text { liposomal dispersion }\end{array}$ & $105 \pm 17$ & -30 & 20 & $\begin{array}{l}\text { Insulin was rapidly } \\
\text { released in both } 0.1 \mathrm{M} \\
\mathrm{HCl} \text { and phosphate } \\
\text { buffer pH } 6.8 \text { media and } \\
\text { complete release was } \\
\text { achieved almost after } \\
30 \mathrm{~min} .\end{array}$ & $\begin{array}{l}\text { Oral: } \\
50 \\
\text { SC: } \\
1\end{array}$ & $\begin{array}{l}\text { A significant effect was } \\
\text { observed at } 2 \mathrm{~h} \text { after oral } \\
\text { administration as the } \\
\text { blood glucose level was } \\
\text { reduced by almost } 17 \% \text { of } \\
\text { the initial level and the } \\
\text { effect was prolonged for } \\
\text { up to } 8 \mathrm{~h} \text {. }\end{array}$ & [101] \\
\hline $\begin{array}{c}\text { Low MW 50-190 kDa, } \\
\geq 75.0 \% \\
\text { deacetylated chitosan } \\
+ \\
\text { Iota-carrageenan (CMCi) }\end{array}$ & Polyelectrolyte complexation method & $613 \pm 41$ & $52.5 \pm 0.5$ & $86.9 \pm 2.6$ & $\begin{array}{c}\text { After } 2 \mathrm{~h} \mathrm{in} \mathrm{simulated} \\
\text { gastric fluid (SGF), } \\
\text { the release of insulin } \\
\text { from the nanoparticles } \\
\text { was only } 4.91 \pm 0.24 \% \text {, } \\
\text { while in SIF, the release of } \\
\text { insulin was } \\
86.64 \pm 2.20 \% .\end{array}$ & - & - & [102] \\
\hline
\end{tabular}


Table 2. Cont

\begin{tabular}{|c|c|c|c|c|c|c|c|c|}
\hline Nanocarrier & Preparation Method & Particle Size $(\mathrm{nm})$ & Zeta Potential (mV) & Entrapment Efficiency (\%) & In Vitro Insulin Release & Dose (IU/kg) & In Vivo Observation & Reference \\
\hline $\begin{array}{c}\text { Chitosan, } \\
\text { alloxan monohydrate } \\
+ \\
\text { Alginate } \\
+ \\
\text { Polyurethane } \\
\text { (PU-ALG/CS NPs) }\end{array}$ & Polyelectrolyte complexation method & 90-110 & 38.5 & 90 & $\begin{array}{l}\text { There was a slight insulin } \\
\text { release ( } 13.7 \% \text { ) at pH } 1.2 \\
\text { up to } 1 \mathrm{~h} \text {, while } \\
\text { moderately release (up to } \\
50 \% \text { ) till } 10 \text { th } \mathrm{h} \text { in } \mathrm{pH} 6.8 \\
\text { buffer solution, whereas } \\
\text { sustained release of } \\
\text { insulin was noticed } \\
\text { at pH } 7.4 \text { from } 11 \text { th } \mathrm{h}, \\
\text { and reached the } \\
\text { maximum insulin release } \\
\text { after } 20 \text { th } \mathrm{h}(98.32 \%) .\end{array}$ & $\begin{array}{l}\text { Oral: } \\
50 \text { and } 100 \\
\text { SC: } \\
5\end{array}$ & $\begin{array}{l}\text { Blood glucose level was } \\
\text { reduced up to } 98 \mathrm{mg} / \mathrm{dL} \\
\text { for the insulin doses of } \\
100 \mathrm{IU} / \mathrm{kg} \text {, and } 113 \mathrm{mg} / \mathrm{dL} \\
\text { for the } 50 \mathrm{IU} / \mathrm{kg} \text { dose } \\
\text { at the } 10 \mathrm{th} \mathrm{h} .\end{array}$ & [94] \\
\hline $\begin{array}{c}\text { Chitosan } \\
95 \% \text { DD } \\
+ \\
\text { Alginate } \\
+ \\
\text { Methoxypolyethylene glycol } \\
\text { (mPEG, MW 5.0 kDa) } \\
+ \\
\text { D, L-Lactide (LA) } \\
+ \\
\text { Glycolide (GA) } \\
+ \\
\text { Poly } \\
\text { (vinyl alcohol)1788 } \\
\text { low-viscosity (PVA) } \\
+ \\
\text { poly (ethylene glycol)-block-poly } \\
\text { (propylene glycol)-block-poly } \\
\text { (ethylene glycol) } \\
\text { (F68, Mw 8.4 kDa) }\end{array}$ & $\begin{array}{c}\text { Double-emulsion }(\mathrm{w} / \mathrm{o} / \mathrm{w}) \text { solvent } \\
\text { evaporation method } \\
+ \\
\text { Polyelectrolyte complexation }\end{array}$ & $\begin{array}{c}\text { CS NP } \\
224.4 \pm 13.8 \\
\text { Alg NP } \\
260.1 \pm 17.1\end{array}$ & $\begin{array}{c}\text { CS NP } \\
+13.7 \pm 1.6 \\
\text { Alg NP } \\
-55.7 \pm 6.6\end{array}$ & $\begin{array}{c}\text { CS NP } \\
55.2 \pm 7.0 \\
\text { Alg NP } \\
81.5 \pm 7.4\end{array}$ & $\begin{array}{c}\text { The insulin loaded PEC } \\
\text { enabled a slight insulin } \\
\text { release (only } 13.91 \% \text { ) } \\
\text { in SGF (pH 1.2) within } \\
\text { the first } 4 \mathrm{~h} \text {. } \\
\text { In contrast, rapid rising } \\
\text { rate in the first } 4 \mathrm{~h} \\
(38.03 \% \text { ) at the pH } 6.8 \\
\text { took place, and the } \\
\text { cumulative drug release } \\
\text { increased to } 51.57 \% \\
\text { within } 10 \mathrm{~h} \text {, and reached } \\
80.54 \% \text { after } 60 \mathrm{~h} \text {. }\end{array}$ & $\begin{array}{l}\text { Oral: } \\
60 \\
\text { SC: } \\
5\end{array}$ & $\begin{array}{l}\text { The blood glucose level } \\
\text { decreased after the oral } \\
\text { administration of } \\
\text { insulin-loaded PEC with } \\
\text { the maximal blood } \\
\text { glucose reduction of } 30 \% \\
\text { at } 8 \mathrm{~h} \text {, and } 20 \% \text { after } 12 \mathrm{~h} \text {. } \\
\text { Insulin concentration } \\
\text { in plasma was increased } \\
\text { gradually and resulted } \\
\text { in a maximum } \\
\text { plasma concentration } \\
\left(41.5 \pm 4.4 \mu \mathrm{IU} \mathrm{mL}^{-1}\right) \\
\text { at } 10 \mathrm{~h} .\end{array}$ & [95] \\
\hline $\begin{array}{c}\text { Chitosan (95\% deacetylated; } \\
\text { MW } 150 \mathrm{kDa}) \\
+ \\
\text { Dz13Scr }\end{array}$ & Complex coacervation & $534 \pm 24$ & $14.57 \pm 1.1$ & $79.96 \pm 3.96$ & $\begin{array}{c}\text { Only } 14.03 \% \text { of } \\
\text { cumulative insulin } \\
\text { released at } \mathrm{pH} 2, \\
\text { while approximately } 85 \% \\
\text { of insulin was released } \\
\text { after } 10 \mathrm{~h} \\
\text { at } \mathrm{pH} 6.8 \text { phosphate } \\
\text { buffer solution. }\end{array}$ & - & - & [97] \\
\hline
\end{tabular}




\section{Chitosan Modification}

Chitosan poor solubility in water and most organic solvents hinders its applications in various fields. One of the unique characteristics that confers chitosan a superior polymer to other polysaccharide is the ease of chemical modifications thanks to its chemical structure, especially in the C-2 position, that is prone to chemical reactions. Chemical modification is not only able to improve the physical and chemical attributes of chitosan, but also its biological characteristics. In addition, chemically modified chitosan can retain its unique properties and expand the application range of chitosan derivatives through introducing new desirable properties [103]. These derivatives have been known to have wider range of solubility compared to chitosan, can protect drugs in the acid environment, increase their release in basic medium and then their permeation (especially for hydrophilic drugs) and also can be targeted for colon-specific delivery [67]. Chitosan possesses three types of reactive functional groups, including, an amino group at the C-6 position, a primary hydroxyl group at the C-6 position and a secondary hydroxyl group at the $\mathrm{C}-3$ position. The amino group at the $\mathrm{C}-6$ position distinguishes chitosan from chitin with reference to its physical, chemical and biological propensities. Hydroxyl group at the C-3 position has poor rotational tendency and exhibits high steric hindrance and reduced ability to react, while modification on at the amino group at C2 or C6-hydroxyl group positions can be easily achieved [104]. The most widely employed method for chemical modulation of chitosan is $\mathrm{N}$-substitution in which the amino group $\left(-\mathrm{NH}_{2}\right)$ of chitosan poses the functional group that reacts [103].

\subsection{Trimethyl Chitosan (TMC)}

TMC is one of the most successfully developed quaternized derivative of chitosan [75]. It is advantageous in term of enhancing the paracellular transport through binding directly to negatively-charged mucus and increasing the retention time of cargo on the mucosal surface prior to opening the tight junctions of epithelial cells [105]. Many researches have synthesised TMC due to its solubility in a wide range of $\mathrm{pH}(1-9)$, thus regardless varying $\mathrm{pH}$ value along GIT, the positive charge is maintained and so the advantageous properties of the polymer [106,107].

TMC was synthesised as a nanoparticle matrix for oral insulin delivery by many experimenters to investigate its favorable characteristics compared to native chitosan. Tsai et al., have reported a potential multifunctional nanoplatform composed of TMC and fucoidan (FD), a polysaccharide that has blood glucose level regulation feature via inhibiting the activity of $\alpha$-amylase and $\alpha$-glucosidase enzymes. The nanoparticles have been formulated via a simple polyelectrolyte complex method between TMC and FD. The prepared nanoparticles were able to modulate the tight junction integrity and so the barrier function of the Caco-2 intestinal epithelial cell monolayer. Both TMC/FC and CS/FC enabled reduction the trans-epithelial electrical resistance (TEER) at $\mathrm{pH}$ 6.5. However, TMC showed its superiority at $\mathrm{pH} 6.8$ and $\mathrm{pH} 7.4$, as TMC/FD nanoparticles exhibited stronger effect ( $38.7 \%$ and $44.5 \%$ of the initial value after $120 \mathrm{~min}$ ) than CS/FD nanoparticles on reducing the TEER. The findings indicated that by increasing the $\mathrm{pH}$ value, permeation enhancement ability of CS has decreased while TMC has remained unchanged. TMC/FD nanoparticles exhibited concentration-dependent $\alpha$-glucosidase inhibitory activity, with an inhibition ratio of $33.2 \%$ at $2 \mathrm{mg} / \mathrm{mL}$. In vitro release study demonstrated that TMC/FC formulation suppressed insulin release in all mediums compared to CS/FC formulation. Almost $90 \%$ of encapsulated insulin released from CS/FD at $\mathrm{pH} 6.8$ vs. $35 \%$ from TMC/FD nanoparticles which may be attributed to the enhanced stability achieved by the positive charge. TMC/FD nanoparticles also demonstrated more protection of insulin against enzymatic degradation than CS/FD nanoparticles ( $57.8 \%$ for TMC/FD vs. $38.9 \%$ for CS/FD nanoparticles after $0.5 \mathrm{~h}$ of digestion). However, it appeared that TMC/FD nanoparticles are yet to improve insulin stability under enzymatic digestion for prolonged duration of $4 \mathrm{~h}$ (remained insulin ratio 25.6\%) [105].

Another work by Omid et al., aimed to prepare an absorption-improving system of insulin-loaded nanoparticles derived from glycyl-glycine (GG) and alanyl-alanine (AA) conjugates of CS and TMC. This formulation can be absorbed by two different mechanisms: firstly, CS and its derivatives have 
displayed enhanced absorption from intestinal epithelium via paracellular pathways through tight junctions opening. Secondly, the conjugation of dipeptide (AA and GG) can promote the absorption as a function of proton-coupled oligopeptide transporters PepT1 and PepT2 in the cell membrane that are specific for oligopeptides with 2-4 amino acids. Thus, the formulation can induce internalisation of the conjugates through PepT1 and/or PepT2 transporters beside the tight junction opening mechanism. The optimised formulations demonstrated small particle size $(157.3-197.7 \mathrm{~nm})$, relatively high zeta potential (24.35-34.37 mV), and improved entrapment efficiency $(70.60 \%-86.52 \%)$. The prepared GG- and AA-conjugated TMC nanoparticles exhibited 2.5-3.3-fold higher permeability of insulin in Caco-2 cell line compared to unmodified TMC nanoparticles. In animal model, oral administration of GG and AA conjugate nanoparticles of TMC demonstrated reasonable increase in serum insulin level (almost $50 \%, 45 \%$ ), with relative bioavailability of $17.19 \%$ and $15.46 \%$, respectively compared with TMC nanoparticles (14.15\%) [106].

TMC, as cationic molecules, possess high affinity towards the negatively-charged mucin that forms the mucus matrix resulting in its mucoadhesive property which increases the retention time and local concentration of the nanoparticles on the mucus layer. However, entrapping within mucin matrix can decrease the direct contact with epithelial cells and increase the probability of the nanoparticle clearance together with the mucus. To circumvent this limitation, Liu et al., prepared nanoparticles of a core composed of insulin and TMC, and a dissociable "mucus-inert" hydrophilic coating of N-(2-hydroxypropyl) methacrylamide copolymer (pHPMA) derivative. Coating with HPMA copolymer on the surface of the mucoadhesive TMC nanoparticles could facilitate permeation of nanoparticles through mucus, by enabling detachment in time to expose the TMC nanoparticles, thus increasing the affinity with cell membrane and fulfilling the subsequent paracellular transport across epithelium. While oral free insulin solution failed to reduce the blood glucose level, both TMC nanoparticles and HPMA-coated TMC nanoparticles render significant hypoglycemic effect as the blood glucose level was decreased by almost $20 \%$ and $36 \%$ at $4 \mathrm{~h}$, and maintained up to $10 \mathrm{~h}$. HPMA-coated TMC nanoparticles at dose of $50 \mathrm{IU} / \mathrm{kg}$, exhibited a relative bioavailability of $8.56 \%$, which is 2.8-fold higher than that of TMC nanoparticles (3.09\%) [108].

Another study by Sheng et al., also encountered similar limitation when they prepared TMC-coated polylactide-co-glycoside (PLGA) nanoparticles (TMC-PLGA NPs). The formulation was designed to overcome the multiple barriers against oral insulin absorption. Although the TMC-PLGA NPs could improve the mucus penetration of insulin in mucus-secreting HT29-MTX cells, it was noticeable that TMC-PLGA NPs moved more slowly through the GIT compared with unmodified PLGA NPs. As a consequence of slow permeability, a considerable amount of insulin might be released in the GIT and would be more susceptible to be degraded by the proteolytic enzymes [109]. Thereby, the same team suggested some modifications to the formulation to modulate the absorption of insulin released from nanoparticles in GIT via incorporating low molecular weight protamine (LMWP) as a cell penetrating peptides-linked insulin conjugates. By adopting this delivery system, the mucoadhesive nanoparticle can promote the retention on the mucus layer, while proteases degrading effect of released insulin-conjugate is avoided as a result of the short distance to the epithelia and the high permeation profile of the conjugates through epithelia. Insulin-LMWP conjugates mucoadhesive nanoparticles showed an oral insulin bioavailability of $17.98 \pm 5.61 \%$, as well as enhanced hypoglycemia effect by two-fold higher than the nanoparticles loaded-mere insulin [110].

\subsection{Carboxymethyl Chitosan (CMCS)}

Besides TMC, chitosan solubility can be improved by another common derivative via carboxymethylation, a hydrophilic modification to yield carboxymethyl chitosan (CMCS) with numerous biomedical applications. This modification enhances chitosan's solubility in natural and basic mediums while the effect on other important characteristics is negated. Carboxymethylation reaction takes place either at $\mathrm{C}-6$ hydroxyl groups or at $\mathrm{NH}_{2}$ moiety to produce $\mathrm{N}, \mathrm{O}$-carboxymethyl chitosan compounds that comprise primary $\left(-\mathrm{NH}_{2}\right)$ or secondary amine group $\left(-\mathrm{NH}-\mathrm{CH}_{2} \mathrm{COOH}\right)$ [111]. 
One of the essential applications of CMCS is a starting material to prepare nanoparticles for protein delivery such as insulin. Recently, Wang et al., have developed $\mathrm{pH}$ responsive nanocarrier composed of CS and CMCS for oral insulin delivery. Two insulin-loaded CMCS/CS nanogels (NGs) with similar shape, size, but opposite surface charges were prepared to investigate the effect of NGs surface charge properties on the absorption sites of small intestine. Ex vivo study exhibited unchanged adhesion and permeation propensities in the duodenum of the rat, while higher adhesion (3-fold) and permeation (1.7-fold) were observed in the jejunum for negatively charged NGs compared to the positive ones. Moreover, in vivo experiment revealed that oral administration of insulin-loaded CMCS/CS-NGs $(-)$ enabled reduction of blood glucose level more efficiently compared to CMCS/CS-NGs (+) at $4 \mathrm{~h}$ $(82.8 \mathrm{mg} / \mathrm{dL}$ vs. $138.6 \mathrm{mg} / \mathrm{dL})$, and this effect was prolonged for up to $11 \mathrm{~h} \mathrm{[112].}$

\subsection{Cyclodextrin-Grafted Chitosan}

Cyclodextrins (CD) are basket-shaped molecules that possess a central hydrophobic cavity and outer hydrophilic shell. The internal hydrophobic cavity surfaces of CDs are capable to form inclusion complexes with drugs of appropriate size. Macromolecules such as insulin exemplifying too large molecules for complete inclusion, can partially be complexed by CDs via their hydrophobic side chains. Surprisingly, even if the macromolecules are partially included into the CD cavity, their physicochemical and biological properties can be significantly improved [113,114].

Chitosan and CD were integrated together to prepare carboxymethyl- $\beta-C D$-grafted CS nanoparticles (CMCD-g-CS nanoparticles) via ionic gelation method $[113,115]$. Song et al., have synthesised CMCD-g-CS by EDC-mediated esterification reaction, then TPP solution was gradually added into the insulin/CMCDg-CS solution for $1 \mathrm{~h}$ under continuous stirring. The prepared nanoparticles exhibited favourable encapsulation efficiency $(57.0 \pm 1.38 \%)$. The in vitro release experiment demonstrated that CMCD-g-CS nanoparticles could efficiently protect encapsulated insulin in acidic medium (only $35.4 \%$ insulin released in SGF) that may account for the free insulin located at the nanoparticle surfaces. A greater extent and higher insulin released was attainable in SIF with a cumulative amount higher than $80 \%$ over $1.5 \mathrm{~h}$ dissolution, achieving bioavailability of $14.54 \%$. Insulin-CMCD-g-CS nanoparticles were advocated to be highly biocompatible with minimised cellular toxicity effects, where more than $80 \%$ cell viability has reported after incubating in nanoparticles solution at a concentration range of $20-120 \mu \mathrm{g} / \mathrm{mL}$ [115].

\subsection{Vitamin B12-Conjugated Chitosan (VitB12-Chi)}

Layer-by-layer (LBL) approach that comprises polyelectrolytes of opposite charges and placed successively onto core surface, have exhibited significant influence on physiochemical and therapeutics attributes of the prepared nanosystem. This method was used to fabricate insulin nanoparticles for oral delivery under mild conditions to avoid protein decomposition by organic solvents or high temperature. Nevertheless, LBL method is a lengthy process and involves repeated adsorption and centrifugation steps that may hinder effective encapsulation. Implementation of vitamin B12 as a transport system has exhibited great interest as a potential approach to promote insulin absorption in GIT and improves its bioavailability [37]. Su et al., have fabricated insulin nanoparticles via LBL technique and conjugated vitamin B12 with chitosan and alginate to produce a nanocomplex (VitB12-Chi-CP nanoparticles). This nanocomplex has formed a complex with intrinsic factor (IF) that subsequently incurred receptor-mediated endocytosis through intestinal epithelia. VitB12-Chi-CP complex has enhanced the water solubility at higher $\mathrm{pH}$ values compared to vitamin $\mathrm{B} 12$ free nanoparticles. It was also found that $14 \%$ of insulin has been transported through Caco- 2 cells monolayer upon incubation with nanocomplex for $6 \mathrm{~h}$ that could be attributed to endocytosis uptake of vitamin B12 and paracellular passage. Moreover, vitB12-Chi-CP nanoparticles also possessed low zeta potential that gave rise to thinner coating formation and thus reduced particle size. In addition, prolonged blood glucose lowering profile was attainable for up to $12 \mathrm{~h}$, despite the delayed onset of action by 1-2 h [116]. Table 3 illustrates the recent examples of nanoparticles-based modified chitosan matrices, their compositions and characterizations. 
Table 3. Insulin-loaded chitosan derivatives-based nanoparticles.

\begin{tabular}{|c|c|c|c|c|c|c|c|c|}
\hline Polymer & Nanocarrier Components & Method of Preparation & $\begin{array}{l}\text { Particle Size, } \\
\text { Zeta Potential }\end{array}$ & $\begin{array}{l}\text { Encapsulation Efficiency, } \\
\text { Drug Loading }\end{array}$ & $\begin{array}{c}\text { In Vitro } \\
\text { Insulin Release }\end{array}$ & Dose & In Vivo Observation & Reference \\
\hline Trimethyl chitosan & $\begin{array}{c}400 \mathrm{KDa} \text { MW, } \\
>90 \% \text { deacetylated TMC+TPP } \\
+ \\
\text { Poly } \\
\text { N-(2-hydroxypropyl) } \\
\text { methacrylamide } \\
\text { (HPMA) (pHPMA) }\end{array}$ & $\begin{array}{l}\text { Mild electrostatic self-assembly } \\
\text { process }\end{array}$ & $\begin{array}{l}163.1 \mathrm{~nm} \\
-3.35 \mathrm{mV}\end{array}$ & $\begin{array}{l}54.1 \pm 1.9 \% \\
26.5 \pm 0.7 \%\end{array}$ & $\begin{array}{c}\text { Rapid insulin release } \\
\text { at pH 2, while within } \\
8 \mathrm{~h} \text {, sustained release } \\
\text { was observed at both } \\
\text { pHs } 6 \text { and } 7.4 . \\
70 \% \text { of insulin released } \\
\text { in presence of trypsin } \\
\text { within } 4 \mathrm{~h} .\end{array}$ & $\begin{array}{c}\text { Oral: } \\
50 \mathrm{IU} / \mathrm{kg} \\
\text { SC: } \\
5 \mathrm{IU} / \mathrm{kg}\end{array}$ & $\begin{array}{l}36 \% \text { decreasing of } \\
\text { blood glucose level } \\
\text { (BDL) at } 4 \mathrm{~h} \text {, and the } \\
\text { effect lasted for } 10 \mathrm{~h} \text {. }\end{array}$ & [108] \\
\hline Trimethyl chitosan & $\begin{array}{c}275 \mathrm{KDa} \text { MW, } \\
95 \% \text { deacetylated chitosan } \\
\text { (CS)/(TMC) } \\
+ \\
\text { Alanyl alanine } \\
\text { (AA) } \\
+ \\
\text { Glycyl-glycine } \\
\text { (GG) }\end{array}$ & Polyelectrolyte complexation & $\begin{array}{c}\text { CS-GG } \\
167.8 \pm 46.1 \mathrm{~nm} \\
25.40 \pm 4.2 \mathrm{mV} \\
\text { CS-AA } \\
185.3 \pm 27.6 \mathrm{~nm} \\
24.62 \pm 3.6 \mathrm{mV} \\
\text { TMC-GG } \\
157.3 \pm 38.5 \mathrm{~nm} \\
34.37 \pm 5.1 \mathrm{mV} \\
\text { TMC-AA } \\
197.7 \pm 31.7 \mathrm{~nm} \\
24.35 \pm 1.9 \mathrm{mV}\end{array}$ & $\begin{array}{c}\text { CS-GG } \\
86.52 \pm 4.7 \% \\
56.81 \pm 6.7 \% \\
\text { CS-AA } \\
77.20 \pm 5.9 \% \\
30.92 \pm 4.6 \% \\
\text { TMC-GG } \\
70.60 \pm 7.2 \% \\
39.07 \pm 2.6 \% \\
\text { TMC-AA } \\
83.08 \pm 6.2 \% \\
37.24 \pm 1.6 \%\end{array}$ & $\begin{array}{l}\text { Burst release of insulin } \\
\text { within the first } 30 \mathrm{~min}, \\
\text { after that insulin has } \\
\text { been released in } \\
\text { a controlled manner } \\
\text { and reached } \\
\text { a maximum of } 83.4 \% \\
\text { in CS-GG, } \\
78.3 \% \text { in CS-AA, } \\
75.9 \% \text { in TMC-GG, } \\
73.9 \% \text { in TMC-AA. }\end{array}$ & $\begin{array}{l}\text { Oral: } \\
20 \mathrm{IU} / \mathrm{kg} \\
\text { SC: } \\
3 \mathrm{IU} / \mathrm{kg}\end{array}$ & $\begin{array}{l}\text { Both TMC-GG and } \\
\text { TMC-AA nanoparticles } \\
\text { reduced the BGL } \\
\text { considerably compared } \\
\text { to oral insulin. } \\
\text { While TMC-nanoparticles } \\
\text { decreased the BGL to } \\
\text { only } 61.3 \% \text { of the initial, } \\
\text { TMC-GG showed } \\
\text { maximum reduction to } \\
46.8 \% \text {, followed by } \\
\text { TMC-AA to } 54 \% \\
\text { after } 8 \mathrm{~h} .\end{array}$ & [106] \\
\hline Trimethyl chitosan & $\begin{array}{c}33 \mathrm{KDa} \text { MW, } \\
\text { 85\% deacetylated TMC } \\
+ \\
\text { Fucoidan (FD) } \\
\text { MW } \\
(31.7 \mathrm{kDa})\end{array}$ & Simple polyelectrolyte complex & $\begin{array}{l}256.7 \pm 4.9 \mathrm{~nm} \\
26.5 \pm 1.1 \mathrm{mV}\end{array}$ & $\begin{array}{l}56.4 \pm 4.3 \% \\
8.6 \pm 2.2 \%\end{array}$ & $\begin{array}{l}\text { At } \mathrm{pH} 2 \text { slow insulin } \\
\text { release at } 38.3 \pm 2.1 \% \\
\text { and } 45.2 \pm 2.7 \% \text { of } \\
\text { TMC/FD and CS/FD, } \\
\text { respectively, while at } \\
\text { pH } 7.4 \text { the release of } \\
\text { insulin was faster, } \\
\text { and more rapid } \\
75.4 \pm 2.2 \% \text { and } \\
93.4 \pm 1.6 \% \text {, respectively. }\end{array}$ & - & - & [105] \\
\hline Carboxymethyl chitosan (CMCS) & $\begin{array}{l}400 \mathrm{KDa} \text { MW, } \\
\text { 95\% deacetylated chitosan }\end{array}$ & Simple ionic gelation & $\begin{array}{c}\text { CMCS/CS-NGs } \\
(-) \\
243 \pm 3.85 \mathrm{~nm} \\
-15.9 \pm 0.45 \\
(+) \\
260 \pm 4.47 \mathrm{~nm} \\
+17.2 \pm 0.49 \mathrm{~nm}\end{array}$ & $\begin{array}{c}\text { CMCS/CS-NGs } \\
(-) \\
73 \pm 6.36 \% \\
29 \pm 3.61 \% \\
(+) \\
74 \pm 8.36 \% \\
27 \pm 4.04 \%\end{array}$ & $\begin{array}{l}\text { Insulin released was } \\
28 \% \text { in SGF and } \\
\text { approximately } 87 \% \\
\text { in SIF. }\end{array}$ & $\begin{array}{l}\text { Oral: } \\
50 \mathrm{IU} / \mathrm{kg} \\
\text { SC: } \\
5 \mathrm{IU} / \mathrm{kg}\end{array}$ & $\begin{array}{c}\text { At } 4 \mathrm{~h} \text {, } \\
\text { the nanoparticles with } \\
\text { negative charge have } \\
\text { made BGL dropped to } \\
82.8 \mathrm{mg} / \mathrm{dL} \text { while } \\
\text { positive ones to } \\
138.6 \mathrm{mg} / \mathrm{dL} \text {, and this } \\
\text { effect prolonged } \\
\text { for } 11 \mathrm{~h}\end{array}$ & [112] \\
\hline
\end{tabular}


Table 3. Cont.

\begin{tabular}{|c|c|c|c|c|c|c|c|c|}
\hline Polymer & Nanocarrier Components & Method of Preparation & $\begin{array}{c}\text { Particle Size, } \\
\text { Zeta Potential }\end{array}$ & $\begin{array}{l}\text { Encapsulation Efficiency, } \\
\text { Drug Loading }\end{array}$ & $\begin{array}{c}\text { In Vitro } \\
\text { Insulin Release }\end{array}$ & Dose & In Vivo Observation & Reference \\
\hline $\begin{array}{l}\text { Carboxymethyl chitosan } \\
\text { (CMCS) }\end{array}$ & $\begin{array}{l}400 \mathrm{KDa} \text { MW, } \\
\text { 95\% deacetylated chitosan }\end{array}$ & Simple ionic gelation & - & - & $\begin{array}{c}\text { CMCSNP }(-): \\
\text { pH } 1.2 \\
(20.7 \% \text { at } 2 \mathrm{~h}), \\
\mathrm{pH} 7 \\
(83.4 \% \text { at } \\
2 \mathrm{~h}) \\
\mathrm{CMCSNP}(+): \\
\mathrm{pH} 1.2 \\
(33.6 \% \text { at } 2 \mathrm{~h}), \\
\mathrm{pH} 7 \\
(71.6 \% \text { at } 2 \mathrm{~h}) \\
\end{array}$ & $\begin{array}{c}\text { Oral: } \\
50 \mathrm{IU} / \mathrm{kg} \\
\text { SC: } \\
5 \mathrm{IU} / \mathrm{kg}\end{array}$ & & [117] \\
\hline $\begin{array}{l}\text { Carboxymethyl- } \beta \text {-cyclodextringrafted } \\
\text { chitosan (CMCD-g-CS) }\end{array}$ & $\begin{array}{c}\text { MW 46K with } 90-95 \% \\
\text { deacetylation } \\
+ \\
\text { d carboxymethyl- } \beta \text {-cyclodextrin } \\
\text { MW } 1591 \\
+ \\
\text { TPP }\end{array}$ & Ionic gelation & $218 \mathrm{~nm}$ & $\begin{array}{c}\mathrm{EE} \\
57.0 \pm 1.38 \%\end{array}$ & $\begin{array}{l}\text { About } 35.4 \pm 0.025 \% \text { of } \\
\text { insulin was rapidly } \\
\text { released in SGF (pH 1.2) } \\
\text { after } 15 \mathrm{~min}, \\
\text { while in SIF (pH 7.4), } \\
\text { after } 120 \text { min the } \\
\text { cumulative amount of } \\
\text { insulin released } \\
\text { increased to } \\
82.9 \pm 0.04 \% .\end{array}$ & $\begin{array}{c}\text { Oral: } \\
50 \mathrm{IU} / \mathrm{kg} \\
\text { SC: } \\
5 \mathrm{IU} / \mathrm{kg}\end{array}$ & $\begin{array}{l}\text { Insulin/CMCD-g-CS } \\
\text { nanoparticles administration } \\
\text { showed gradually } \\
\text { enhanced hypoglycemic } \\
\text { effect. After } 12 \mathrm{~h} \text {, } \\
\text { the BGL was reduced to } \\
51.22 \% \text { of the } \\
\text { initial level. } \\
\text { The nanoparticles } \\
\text { exhibited a relative } \\
\text { bioavailability of } 14.54 \% \text {. }\end{array}$ & on \\
\hline $\begin{array}{l}\text { Vitamin B12-grafted } \\
\text { chitosan }\end{array}$ & $\begin{array}{c}\text { Vitamin B12-grafted chitosan } \\
\text { (75-85\% Deacetyld, } \\
65-95 \mathrm{kDa}) \\
+ \\
\text { alginate }+ \\
\text { calcium } \\
\text { phosphate }\end{array}$ & Micro-emulsion method & $\begin{array}{l}234.83 \mathrm{~nm} \\
32.56 \mathrm{mV}\end{array}$ & $\begin{array}{c}75.16 \% \\
7.83 \%\end{array}$ & $\begin{array}{c}\text { At } \mathrm{pH} 1.2 \text { only } 9.9 \% \\
\text { insulin was released } \\
\text { at } 2 \mathrm{~h} \text {. }\end{array}$ & $\begin{array}{c}\text { Oral: } \\
50 \mathrm{IU} / \mathrm{kg} \\
\text { SC: } \\
5 \mathrm{IU} / \mathrm{kg}\end{array}$ & $\begin{array}{l}\text { BGL reduced to } \\
197 \mathrm{mg} / \mathrm{dL} \text { and } \\
\text { maintained up to } 12 \mathrm{~h} \text {. }\end{array}$ & [116] \\
\hline
\end{tabular}




\section{Chitosan and Chitosan Derivatives as Coating Material for Insulin Nanoparticles}

In the field of drug delivery by means of nanotechnology, chitosan has not only been widely used as a particle-forming polymer, but also as a surface coating. Chitosan as a coating material can be used with different types of nanoparticles such as, polymeric nanoparticles, lipid nanoparticle and metal-based nanoparticles. Many advantages can be obtained through nanoparticle's surface modulating by means of coating with chitosan, including, drug release and stability control, bioavailability improvement of drug loaded, mucoadhesive enhancement and tissue penetration property [118].

Chitosan and chitosan derivatives have been used in several studies as a coating material to protect insulin-loaded nanoparticles, as it is believed to have a vital role in protecting insulin from premature release in the gastric medium and increase the residence time of nanoparticles at the intestinal mucosa upon reaching the small intestine [119]. Chitosan coated nanoparticles can be prepared by either addition of chitosan solution into previously prepared nanoparticle formulations, an easy and frequently described way to coat nanoparticles, or by adding chitosan solution during the nanoparticle formation process.

Lopes et al., prepared insulin-loaded alginate/dextran sulfate nanoparticles coated dually by chitosan and albumin, in order to enhance the permeability through the intestinal epithelial layer. The dual coated nanoparticles have resulted in a higher permeability of insulin across Caco-2/HT29-MTX/Raji B cell monolayer compared to coat-free ones. Drug dissolution results exhibited reduced insulin release $(30 \%)$ in the gastric medium followed by sustained release in the intestinal medium [120]. The second approach is by adding chitosan or chitosan derivative solution during the formation process usually produces so-called core-shell nanoparticles.

As for lipid nanocarriers, chitosan is considered one of the best choices among various polysaccharides as coating materials, because of its positive charge and high reaction tendency with negatively charged liposomal surfaces, thus ensuring firm coating. Chitosan-coated liposomal surface could enhance the stability and bioavailability of liposomes [121]. Shalaby and El-Refaie have prepared chitosan-coated insulin-loaded cationic liposomes. The chitosan coated liposomes exhibited nano-sized at $439.0 \pm 12.3 \mathrm{~nm}$ and zeta potential at $+60.5 \pm 1.9 \mathrm{mV}$. Chitosan-coated insulin-loaded cationic liposomes improved insulin loading efficiency $(87.5 \pm 0.6 \%)$, with prolonged pharmacological effect as the ex vivo intestinal mucoadhesion showed increased tissue residence of chitosan-coated compared to uncoated liposomes. Premature insulin released in simulated gastric fluid was minimised $(18.9 \pm 0.35 \%)$, while high amount $(73.33 \pm 0.68 \%)$ was released in simulated intestinal fluid over $48 \mathrm{~h}$ dissolution [122].

In another study, Moghassemi et al., prepared insulin-loaded niosomes by the reversed-phase evaporation method followed by TCM coating via incubating the suspension in a polymer. The investigation of the ability of TMC-coated niosomes in facilitating the permeability of insulin through Caco-2 cell monolayer, showed that TMC-coated niosomes enabled opening the cells tight junctions of the intestinal membrane model and facilitated the enteral absorption of insulin by 4 -folds as compared to insulin alone [123]. Table 4 illustrates the recent examples of chitosan and chitosan-derivatives as coating materials. 
Table 4. Examples of chitosan and chitosan-derivatives as coating materials.

\begin{tabular}{|c|c|c|c|c|}
\hline Type of Chitosan & Type of Nanoparticles & Preparation Method & Observation & Reference \\
\hline $\begin{array}{c}\text { Chitosan } \\
\text { (30 KDa low MW with } \\
85 \% \text { DD) }\end{array}$ & Liposomes & $\begin{array}{l}\text { Simple thin-film } \\
\text { hydration technique }\end{array}$ & $\begin{array}{c}\text { In vitro: at } \mathrm{pH} 1.2, \\
\text { lower percentage of insulin } \\
\text { released from } \\
\text { CS-coated liposomes } \\
(18.9 \pm 0.35 \%) \text { compared to } \\
(35.9 \pm 0.75 \%) \text { uncoated ones } \\
\text { after } 48 \mathrm{~h} \text {. } \\
\text { At higher } \mathrm{pH}(7.4), \mathrm{CS}-\text { coated } \\
\text { liposomes gradually released } \\
\text { almost } 74 \% \text { of insulin over a } \\
\text { prolonged time of } 48 \mathrm{~h} \text {. } \\
\text { In vivo: Blood glucose level } \\
\text { remarkably decreased after } 1 \mathrm{~h} \text { of } \\
\mathrm{CS}-\text { coated liposomes } \\
\text { administration. BGL continued } \\
\text { lowering until reached its normal } \\
\text { level and maintained it for } 4 \mathrm{~h} \\
\text { (8 } \mathrm{h} \text { from administration). }\end{array}$ & [122] \\
\hline $\begin{array}{c}\text { Chitosan } \\
(50 \mathrm{kDa}, 85 \% \mathrm{DD})\end{array}$ & Solid lipid nanoparticles & $\begin{array}{c}\mathrm{w} / \mathrm{o} / \mathrm{w} \\
\text { emulsion method }\end{array}$ & $\begin{array}{l}\text { In vitro: CS-coated solid lipid } \\
\text { nanoparticles demonstrated better } \\
\text { permeation-enhancing properties } \\
\text { as compared to the uncoated ones } \\
\text { through Caco-2 cell monolayer. } \\
\text { In vivo: CS-coated solid lipid } \\
\text { nanoparticles increased the } \\
\text { hypoglycemic effect and enhanced } \\
\text { the pharmacological availability } \\
\text { to } 17.7 \% \text { compared to } 5.1-8.3 \% \text { of } \\
\text { uncoated solid lipid nanoparticles. }\end{array}$ & [124] \\
\hline
\end{tabular}


Table 4. Cont.

\begin{tabular}{|c|c|c|c|c|}
\hline Type of Chitosan & Type of Nanoparticles & Preparation Method & Observation & Reference \\
\hline $\begin{array}{c}\text { TMC ( } 85 \% \text { DD, } \\
\text { degree of trimethyl } \\
\text { substitution } 50 \% \text { ) }\end{array}$ & $\begin{array}{l}\text { Polymeric nanoparticles } \\
\text { (PLGA-NP) }\end{array}$ & $\begin{array}{l}\text { Double-emulsion solvent } \\
\text { evaporative method }\end{array}$ & $\begin{array}{l}\text { In vitro: compared with } \\
\text { PLGA nanoparticles, } \\
\text { TMC-PLGA nanoparticles } \\
\text { relatively protected insulin from } \\
\text { enzymatic degradation in the GIT. } \\
\text { TMC-coated nanoparticles } \\
\text { showed stronger mucoadhesive } \\
\text { and mucus-penetrating capacity } \\
\text { through HT29-MTX cells. } \\
\text { The cellular uptake of insulin of } \\
\text { TMC-PLGA nanoparticles was } \\
\text { dramatically higher than } \\
\text { uncoated PLGA nanoparticles } \\
\text { through HT29-MTX cells without } \\
\text { a mucus layer, while the amount } \\
\text { of insulin penetrated the mucus } \\
\text { layer was } 2 \text { folds greater for the } \\
\text { coated TMC-PLGA nanoparticles. } \\
\text { In vivo: } 40 \% \text { of TMC-PLGA } \\
\text { nanoparticles could attach to the } \\
\text { lower part of the small intestine } \\
\text { prolonging the retention time } \\
\text { at the absorption site while most } \\
\text { of the PLGA nanoparticles moved } \\
\text { to the colon within } 3 \mathrm{~h} \text {. } \\
\text { TMC-PLGA nanoparticles } \\
\text { decreased the BGL rapidly to } 70 \% \\
\text { of the initial level after } 7 \mathrm{~h} \text {, } \\
\text { and continued to decrease over } \\
12 \mathrm{~h} \text {. TMC coated nanoparticles } \\
\text { also had higher pharmacological } \\
\text { availability of } 11.82 \% \text { compared to } \\
5.93 \% \text { of uncoated ones. }\end{array}$ & [109] \\
\hline $\begin{array}{c}\text { TMC ( } 85 \% \text { DD, } \\
\text { degree of trimethyl } \\
\text { substitution } 50 \% \text { ) }\end{array}$ & $\begin{array}{c}\text { Polymeric nanoparticles } \\
\text { (PLGA-NP) } \\
+ \\
\text { (LMW protamine } \\
\text { conjugated insulin) }\end{array}$ & $\begin{array}{l}\text { Ultrasound sonication, } \\
\text { double emulsion }\end{array}$ & $\begin{array}{l}\text { In vitro: the mucoadhesive } \\
\text { TMC-coated PLGA nanoparticles } \\
\text { gave effective protection to } \\
\text { encapsulated insulin or } \\
\text { insulin-LMW protamine as only } \\
5 \% \text { of insulin released after } 1 \mathrm{~h} \\
\text { at SGF of } 1.2 \mathrm{pH} \text {, while } 40 \% \\
\text { at SGF with pepsin compared to } \\
90 \% \text { digestion of insulin or } \\
\text { insulin-LMW protamine } \\
\text { in enzyme-containing SGF } \\
\text { within } 5 \text { min. } \\
\text { Coated nanoparticles significantly } \\
\text { improved insulin permeability } \\
\text { through Caco-2 cells. } \\
\text { Insulin permeation coefficient of } \\
\text { insulin-LMW protamine coated } \\
\text { nanoparticles was } 10 \text {-fold higher } \\
\text { than that of insulin solution. } \\
\text { In vivo: pharmacological availability } \\
\text { has been remarkably enhanced } \\
\text { (17.98\%) from insulin-LMW } \\
\text { protamine coated nanoparticles, } \\
\text { compared to } 0.91 \text { of the free } \\
\text { insulin-LMW conjugates. }\end{array}$ & [110] \\
\hline
\end{tabular}

\section{Conclusions}

This review demonstrated that extensive research activities have been devoted on the application of insulin nanoparticles-based chitosan/chitosan derivatives. Successful loading of insulin and the ability of modulating the size, surface charge, and insulin release confers chitosan nanoparticles a promising tool for oral insulin delivery. Verities of method preparations could impart a desired attribute to the prepared nanoparticles. Compared to sole oral administration of insulin, chitosan nanocarriers have significantly improved the bioavailability and blood glucose lowering propensities. This is mainly attributed to the mucoadhesion characteristic of chitosan to prolong the residence time of the nanoparticle near to the absorption sites in the intestinal region and facilitate insulin transport either transcellularly or intracellularly to blood capillaries, heading to the liver via the portal vein. Chitosan derivatives are 
introduced to improve chitosan solubility and widen its application as a drug delivery system, while maintaining its useful properties. Also, modifying chitosan could have potential applications to control cargo release throughout GIT and surface charge of the prepared nanoparticles to further protect and promote insulin absorption, and hence the bioavailability. In addition, chitosan/chitosan derivatives can be applied as a coat for nanoformulation as an additional use to meet a specific desired goal.

Author Contributions: Writing, review, and editing, S.S., M.A., N.A.N.; visualization, S.S.; supervision, M.A.; project administration, M.A.; funding acquisition, M.A.; formatting, N.A.N. All authors have read and agreed to the published version of the manuscript.

Funding: This research was funded by Universiti Sultan Zainal Abidin through UniSZA/2018/DPU/07 grant.

Acknowledgments: The authors wish to express their heart-felt gratitude to Universiti Sultan Zainal Abidin for grant support.

Conflicts of Interest: The authors declare no conflict of interest.

\section{References}

1. Un Kim, J.; Muhammad Shahbaz, H.; Lee, H.; Kim, T.; Yang, K.; Hoon Roh, Y.; Park, J. Optimization of Phytic Acid-Crosslinked Chitosan Microspheres for Oral Insulin Delivery Using Responsive Surface Methodology. Int. J. Pharm. 2020, 588, 119736. [CrossRef] [PubMed]

2. Vieira, R.; Souto, S.B.; Sánchez-López, E.; López Machado, A.; Severino, P.; Jose, S.; Santini, A.; Fortuna, A.; García, M.L.; Silva, A.M. Sugar-Lowering Drugs for Type 2 Diabetes Mellitus and Metabolic Syndrome-Review of Classical and New Compounds: Part-I. Pharmaceuticals 2019, 12, 152. [CrossRef] [PubMed]

3. Yang, Y.; Liu, Y.; Chen, S.; Cheong, K.-L.; Teng, B. Carboxymethyl $\beta$-Cyclodextrin Grafted Carboxymethyl Chitosan Hydrogel-Based Microparticles for Oral Insulin Delivery. Carbohydr. Polym. 2020, 246, 116617. [CrossRef] [PubMed]

4. Lopes, M.A.; Abrahim, B.A.; Cabral, L.M.; Rodrigues, C.R.; Seiça, R.M.F.; de Baptista Veiga, F.J.; Ribeiro, A.J. Intestinal Absorption of Insulin Nanoparticles: Contribution of M Cells. Nanomed. Nanotechnol. Biol. Med. 2014, 10, 1139-1151. [CrossRef]

5. Patra, J.K.; Das, G.; Fraceto, L.F.; Campos, E.V.R.; Rodriguez-Torres, M.D.P.; Acosta-Torres, L.S.; Diaz-Torres, L.A.; Grillo, R.; Swamy, M.K.; Sharma, S.; et al. Nano Based Drug Delivery Systems: Recent Developments and Future Prospects. J. Nanobiotechnol. 2018, 16, 71. [CrossRef]

6. El-Say, K.M.; El-Sawy, H.S. Polymeric Nanoparticles: Promising Platform for Drug Delivery. Int. J. Pharm. 2017, 528, 675-691. [CrossRef]

7. Santalices, I.; Gonella, A.; Torres, D.; Alonso, M.J. Advances on the Formulation of Proteins Using Nanotechnologies. J. Drug Deliv. Sci. Technol. 2017, 42, 155-180. [CrossRef]

8. Sadeghi, S.; Lee, W.K.; Kong, S.N.; Shetty, A.; Drum, C.L. Oral Administration of Protein Nanoparticles: An Emerging Route to Disease Treatment. Pharmacol. Res. 2020, 158, 104685. [CrossRef]

9. Zhang, T.; Tang, J.Z.; Fei, X.; Li, Y.; Song, Y.; Qian, Z.; Peng, Q. Can Nanoparticles and Nano-protein Interactions Bring a Bright Future for Insulin Delivery? Acta Pharm. Sin. B 2020. [CrossRef]

10. Mohammed, M.A.; Syeda, J.T.M.; Wasan, K.M.; Wasan, E.K. An Overview of Chitosan Nanoparticles and Its Application in Non-Parenteral Drug Delivery. Pharmaceutics 2017, 9, 53. [CrossRef]

11. Gardouh, A.R.; Attia, M.A.; Enan, E.T.; Elbahaie, A.M.; Fouad, R.A.; El-Shafey, M.; Youssef, A.M.; Alomar, S.Y.; Ali, Z.A.-E.; Zaitone, S.A.; et al. Synthesis and Antitumor Activity of Doxycycline Polymeric Nanoparticles: Effect on Tumor Apoptosis in Solid Ehrlich Carcinoma. Molecules 2020, 25, 3230. [CrossRef] [PubMed]

12. Liao, Z.; Wong, S.W.; Yeo, H.L.; Zhao, Y. Nanocarriers for Cancer Treatment: Clinical Impact and Safety. NanoImpact 2020, 20, 100253. [CrossRef]

13. Wong, K.H.; Lu, A.; Chen, X.; Yang, Z. Natural Ingredient-Based Polymeric Nanoparticles for Cancer Treatment. Molecules 2020, 25, 3620. [CrossRef] [PubMed]

14. Cheng, H.; Huang, S.; Huang, G. Design and Application of Oral Colon Administration System. J. Enzym. Inhib. Med. Chem. 2019, 34, 1590-1596. [CrossRef] [PubMed] 
15. Ciro, Y.; Rojas, J.; Alhajj, M.J.; Carabali, G.A.; Salamanca, C.H. Production and Characterization of Chitosan-Polyanion Nanoparticles by Polyelectrolyte Complexation Assisted by High-Intensity Sonication for the Modified Release of Methotrexate. Pharmaceuticals 2020, 13, 11. [CrossRef] [PubMed]

16. Miao, T.; Wang, J.; Zeng, Y.; Liu, G.; Chen, X. Polysaccharide-based Controlled Release Systems for Therapeutics Delivery and Tissue Engineering: From Bench to Bedside. Adv. Sci. 2018, 5, 1700513. [CrossRef] [PubMed]

17. Diolosà, M.; Donati, I.; Turco, G.; Cadenaro, M.; Di Lenarda, R.; Breschi, L.; Paoletti, S. Use of Methacrylate-Modified Chitosan to Increase the Durability of Dentine Bonding Systems. Biomacromolecules 2014, 15, 4606-4613. [CrossRef] [PubMed]

18. Taubner, T.; Marounek, M.; Synytsya, A. Preparation and Characterization of Hydrophobic and Hydrophilic Amidated Derivatives of Carboxymethyl Chitosan and Carboxymethyl $\beta$-Glucan. Int. J. Biol. Macromol. 2020, 163, 1433-1443. [CrossRef] [PubMed]

19. Alai, M.S.; Lin, W.J.; Pingale, S.S. Application of Polymeric Nanoparticles and Micelles in Insulin Oral Delivery. J. Food Drug Anal. 2015, 23, 351-358. [CrossRef] [PubMed]

20. Adibah, W.N.; Ahmad, W.; Mahmod, H.; Ali, A.M. A Review of Medicinal Plants and Daily Foods Used in Southeast Asia Possessing Antidiabetic Activity. J. Agrobiotechnol. 2019, 10, 17-35.

21. Jin, X.; Zhu, D.D.; Chen, B.Z.; Ashfaq, M.; Guo, X.D. Insulin Delivery Systems Combined with Microneedle Technology. Adv. Drug Deliv. Rev. 2018, 127, 119-137. [CrossRef] [PubMed]

22. Nawi, A.; Mamat, M.; Ahmad, W.M. The Factors That Contribute to Diabetes Mellitus in Malaysia: Alternative Linear Regression Model Approach in the Health Field Involving Diabetes Mellitus Data. Int. J. Public Heal. Clin. Sci. 2018, 5, 2289-7577.

23. Zhang, Y.; Yu, J.; Kahkoska, A.R.; Wang, J.; Buse, J.B.; Gu, Z. Advances in Transdermal Insulin Delivery. Adv. Drug Deliv. Rev. 2019, 139, 51-70. [CrossRef] [PubMed]

24. Wong, C.Y.; Martinez, J.; Dass, C.R. Oral Delivery of Insulin for Treatment of Diabetes: Status Quo, Challenges and Opportunities. J. Pharm. Pharmacol. 2016, 68, 1093-1108. [CrossRef] [PubMed]

25. Robinson, S.D.; Safavi-Hemami, H. Insulin as a Weapon. Toxicon 2016, 123, 56-61. [CrossRef] [PubMed]

26. Sun, S.; Liang, N.; Hiromitsu Yamamoto, Y.K.; Cui, F.; Yan, P. Ph-Sensitive Poly(Lactide-Co-Glycolide) Nanoparticle Composite Microcapsules for Oral Delivery of Insulin. Int. J. Nanomed. 2015, 10, 3489-3498. [CrossRef]

27. Matteucci, E.; Giampietro, O.; Covolan, V.; Giustarini, D.; Fanti, P.; Rossi, R. Insulin Administration: Present Strategies and Future Directions for a Noninvasive (Possibly More Physiological) Delivery. Drug Des. Devel. Ther. 2015, 9, 3109-3118. [CrossRef]

28. Liu, L.; Zhang, Y.; Yu, S.; Zhang, Z.; He, C.; Chen, X. PH- and Amylase-Responsive Carboxymethyl Starch/Poly(2-Isobutyl-Acrylic Acid) Hybrid Microgels as Effective Enteric Carriers for Oral Insulin Delivery. Biomacromolecules 2018, 19, 2123-2136. [CrossRef]

29. Easa, N.; Alany, R.; Carew, M.; Vangala, A. A Review of Non-Invasive Insulin Delivery Systems for Diabetes Therapy in Clinical Trials over the Past Decade. Drug Discov. Today 2018. [CrossRef]

30. Gedawy, A.; Martinez, J.; Al-Salami, H.; Dass, C.R. Oral Insulin Delivery: Existing Barriers and Current Counter-Strategies. J. Pharm. Pharmacol. 2018, 70, 197-213. [CrossRef]

31. Shan, W.; Zhu, X.; Liu, M.; Li, L.; Zhong, J.; Sun, W.; Zhang, Z.; Huang, Y. Overcoming the Diffusion Barrier of Mucus and Absorption Barrier of Epithelium by Self-Assembled Nanoparticles for Oral Delivery of Insulin. ACS Nano 2015, 9, 2345-2356. [CrossRef]

32. Wong, C.Y.; Al-Salami, H.; Dass, C.R. Recent Advancements in Oral Administration of Insulin-Loaded Liposomal Drug Delivery Systems for Diabetes Mellitus. Int. J. Pharm. 2018, 549, 201-217. [CrossRef] [PubMed]

33. Odenwald, M.A.; Turner, J.R. The Intestinal Epithelial Barrier: A Therapeutic Target? Nat. Rev. Gastroenterol. Hepatol. 2017, 14, 9-21. [CrossRef] [PubMed]

34. Vancamelbeke, M.; Vermeire, S. The Intestinal Barrier: A Fundamental Role in Health and Disease. Expert Rev. Gastroenterol. Hepatol. 2017, 00, 1-14. [CrossRef] [PubMed]

35. Araújo, F.; Martins, C.; Azevedo, C.; Sarmento, B. Chemical Modification of Drug Molecules as Strategy to Reduce Interactions with Mucus. Adv. Drug Deliv. Rev. 2017, 124, 98-106. [CrossRef] 
36. Muheem, A.; Shakeel, F.; Asadullah, M.; Anwar, M.; Mallick, N.; Kumar, G.; Husain, M.; Jalees, F. A Review on the Strategies for Oral Delivery of Proteins and Peptides and Their Clinical Perspectives. Saudi Pharm. J. 2016, 24, 413-428. [CrossRef]

37. Wong, C.Y.; Al-Salami, H.; Dass, C.R. Potential of Insulin Nanoparticle Formulations for Oral Delivery and Diabetes Treatment. J. Control. Release 2017, 264, 247-275. [CrossRef]

38. McClements, D.J. Encapsulation, Protection, and Delivery of Bioactive Proteins and Peptides Using Nanoparticle and Microparticle Systems: A Review. Adv. Colloid Interface Sci. 2018, 253, 1-22. [CrossRef]

39. Lundquist, P.; Artursson, P. Oral Absorption of Peptides and Nanoparticles across the Human Intestine: Opportunities, Limitations and Studies in Human Tissues. Adv. Drug Deliv. Rev. 2016, 106, 256-276. [CrossRef]

40. Chen, M.; Sonaje, K.; Chen, K.; Sung, H. Biomaterials A Review of the Prospects for Polymeric Nanoparticle Platforms in Oral Insulin Delivery. Biomaterials 2011, 32, 9826-9838. [CrossRef]

41. Sarode, S.; Upadhyay, P.; Khosa, M.A.; Mak, T.; Shakir, A.; Song, S.; Ullah, A. Overview of Wastewater Treatment Methods with Special Focus on Biopolymer Chitin-Chitosan. Int. J. Biol. Macromol. 2019, 121, 1086-1100. [CrossRef] [PubMed]

42. Rinaudo, M. Chitin and Chitosan: Properties and Applications. Prog. Polym. Sci. 2006, 31, 603-632. [CrossRef]

43. Hosseinnejad, M.; Jafari, S.M. Evaluation of Different Factors Affecting Antimicrobial Properties of Chitosan. Int. J. Biol. Macromol. 2016, 85, 467-475. [CrossRef] [PubMed]

44. Nurhayati, Y.; Manaf, A.A.; Osman, H.; Bakar, A.; Abdullah, C.; Yew, J.; Tang, H. Malaysian Journal of Applied Sciences Effect of Chitosan Oligosaccharides on the Growth of Bifidobacterium Species. Malays. J. Appl. Sci. 2016, 1, 13-23.

45. Li, L.; Yang, L.; Li, M.; Zhang, L. A Cell-Penetrating Peptide Mediated Chitosan Nanocarriers for Improving Intestinal Insulin Delivery. Carbohydr. Polym. 2017, 174, 182-189. [CrossRef] [PubMed]

46. Bravo-Anaya, L.M.; Fernández-Solís, K.G.; Rosselgong, J.; Nano-Rodríguez, J.L.E.; Carvajal, F.; Rinaudo, M. Chitosan-DNA Polyelectrolyte Complex: Influence of Chitosan Characteristics and Mechanism of Complex Formation. Int. J. Biol. Macromol. 2019. [CrossRef] [PubMed]

47. Jangra, A.; Lukhi, M.M.; Sulakhiya, K.; Baruah, C.C.; Lahkar, M. Protective Effect of Mangiferin against Lipopolysaccharide-Induced Depressive and Anxiety-like Behaviour in Mice. Eur. J. Pharmacol. 2014, 740, 337-345. [CrossRef]

48. Chang, A.K.T.; Frias, R.R.; Alvarez, L.V.; Bigol, U.G.; Guzman, J.P.M.D. Comparative Antibacterial Activity of Commercial Chitosan and Chitosan Extracted from Auricularia Sp. Biocatal. Agric. Biotechnol. 2019, 17, 189-195. [CrossRef]

49. Gibot, L.; Chabaud, S.; Bouhout, S.; Bolduc, S.; Auger, F.A.; Moulin, V.J. Anticancer Properties of Chitosan on Human Melanoma Are Cell Line Dependent. Int. J. Biol. Macromol. 2015, 72, 370-379. [CrossRef]

50. Miguel, S.P.; Moreira, A.F.; Correia, I.J. Chitosan Based-Asymmetric Membranes for Wound Healing: A Review. Int. J. Biol. Macromol. 2019, 127, 460-475. [CrossRef]

51. Ahsan, S.M.; Thomas, M.; Reddy, K.K.; Sooraparaju, S.G.; Asthana, A.; Bhatnagar, I. Chitosan as Biomaterial in Drug Delivery and Tissue Engineering. Int. J. Biol. Macromol. 2018, 110, 97-109. [CrossRef] [PubMed]

52. Mujtaba, M.; Morsi, R.E.; Kerch, G.; Elsabee, M.Z.; Kaya, M.; Labidi, J.; Khawar, K.M. Current Advancements in Chitosan-Based Film Production for Food Technology; A Review. Int. J. Biol. Macromol. 2019, 121, 889-904. [CrossRef] [PubMed]

53. Baghdan, E.; Pinnapireddy, S.R.; Strehlow, B.; Engelhardt, K.H.; Schäfer, J.; Bakowsky, U. Lipid Coated Chitosan-DNA Nanoparticles for Enhanced Gene Delivery. Int. J. Pharm. 2018, 535, 473-479. [CrossRef] [PubMed]

54. Shahid-ul-Islam; Butola, B.S. Recent Advances in Chitosan Polysaccharide and Its Derivatives in Antimicrobial Modification of Textile Materials. Int. J. Biol. Macromol. 2019, 121, 905-912. [CrossRef] [PubMed]

55. Khlibsuwan, R.; Pongjanyakul, T. Chitosan-Clay Matrix Tablets for Sustained-Release Drug Delivery: Effect of Chitosan Molecular Weight and Lubricant. J. Drug Deliv. Sci. Technol. 2016, 35, 303-313. [CrossRef]

56. He, T.; Wang, W.; Chen, B.; Wang, J.; Liang, Q.; Chen, B. 5-Fluorouracil Monodispersed Chitosan Microspheres: Microfluidic Chip Fabrication with Crosslinking, Characterization, Drug Release and Anticancer Activity. Carbohydr. Polym. 2020, 236, 116094. [CrossRef] 
57. El-Alfy, E.A.; El-Bisi, M.K.; Taha, G.M.; Ibrahim, H.M. Preparation of Biocompatible Chitosan Nanoparticles Loaded by Tetracycline, Gentamycin and Ciprofloxacin as Novel Drug Delivery System for Improvement the Antibacterial Properties of Cellulose Based Fabrics. Int. J. Biol. Macromol. 2020, 161, 1247-1260. [CrossRef]

58. Stie, M.B.; Gätke, J.R.; Wan, F.; Chronakis, I.S.; Jacobsen, J.; Nielsen, H.M. Swelling of Mucoadhesive Electrospun Chitosan/Polyethylene Oxide Nanofibers Facilitates Adhesion to the Sublingual Mucosa. Carbohydr. Polym. 2020, 242, 116428. [CrossRef]

59. De Oliveira, R.L.; da Silva, M.F.; da Silva, S.P.; Cavalcanti, J.V.F.L.; Converti, A.; Porto, T.S. Immobilization of a Commercial Aspergillus Aculeatus Enzyme Preparation with Fructosyltransferase Activity in Chitosan Beads: A Kinetic/Thermodynamic Study and Fructo-Oligosaccharides Continuous Production in Enzymatic Reactor. Food Bioprod. Process. 2020, 122, 169-182. [CrossRef]

60. Da Silva, T.N.; Reynaud, F.; de Souza Picciani, P.H.; de Holanda e Silva, K.G.; Barradas, T.N. Chitosan-Based Films Containing Nanoemulsions of Methyl Salicylate: Formulation Development, Physical-Chemical and in Vitro Drug Release Characterization. Int. J. Biol. Macromol. 2020, 164, 2558-2568. [CrossRef]

61. Dehghan-Baniani, D.; Chen, Y.; Wang, D.; Bagheri, R.; Solouk, A.; Wu, H. Injectable in Situ Forming Kartogenin-Loaded Chitosan Hydrogel with Tunable Rheological Properties for Cartilage Tissue Engineering. Colloids Surf. B Biointerfaces 2020, 192, 111059. [CrossRef] [PubMed]

62. Tian, L.; Singh, A.; Singh, A.V. Synthesis and Characterization of Pectin-Chitosan Conjugate for Biomedical Application. Int. J. Biol. Macromol. 2020, 153, 533-538. [CrossRef] [PubMed]

63. Ali, A.; Ahmed, S. A Review on Chitosan and Its Nanocomposites in Drug Delivery. Int. J. Biol. Macromol. 2018, 109, 273-286. [CrossRef]

64. Situ, W.; Xiang, T.; Liang, Y. Chitosan-Based Particles for Protection of Proteins during Storage and Oral Administration. Int. J. Biol. Macromol. 2018, 117, 308-314. [CrossRef] [PubMed]

65. Bakshi, P.S.; Selvakumar, D.; Kadirvelu, K.; Kumar, N.S. Chitosan as an Environment Friendly Biomaterial-A Review on Recent Modifications and Applications. Int. J. Biol. Macromol. 2020, 150, 1072-1083. [CrossRef] [PubMed]

66. Cheung, R.C.F.; Ng, T.B.; Wong, J.H.; Chan, W.Y. Chitosan: An Update on Potential Biomedical and Pharmaceutical Applications. Mar. Drugs 2015, 13, 5156-5186. [CrossRef] [PubMed]

67. Ahmed, T.A.; Aljaeid, B.M. Preparation, Characterization, and Potential Application of Chitosan, Chitosan Derivatives, and Chitosan Metal Nanoparticles in Pharmaceutical Drug Delivery. Drug Des. Devel. Ther. 2016, 10, 483-507. [CrossRef] [PubMed]

68. Castro, P.M.; Raquel, A.; Sarmento, B.; Pintado, M. Recent Insights in the Use of Nanocarriers for the Oral Delivery of Bioactive Proteins and Peptides. Peptides 2018. [CrossRef]

69. Rizvi, S.A.A.; Saleh, A.M. Applications of Nanoparticle Systems in Drug Delivery Technology. Saudi Pharm. J. 2017, 26, 64-70. [CrossRef]

70. Luo, Y.Y.; Xiong, X.Y.; Tian, Y.; Li, Z.L.; Gong, Y.C.; Li, Y.P. A Review of Biodegradable Polymeric Systems for Oral Insulin Delivery. Drug Deliv. 2015, 23, 1882-1891. [CrossRef]

71. Calvo, P.; Remuñán-López, C.; Vila-Jato, J.L.; Alonso, M.J. Novel Hydrophilic Chitosan-Polyethylene Oxide Nanoparticles as Protein Carriers. J. Appl. Polym. Sci. 1997, 63, 125-132. [CrossRef]

72. Divya, K.; Jisha, M.S. Chitosan Nanoparticles Preparation and Applications. Environ. Chem. Lett. 2018, 16, 101-112. [CrossRef]

73. Brunel, F.; Véron, L.; David, L.; Domard, A.; Delair, T. A Novel Synthesis of Chitosan Nanoparticles in Reverse Emulsion. Langmuir 2008, 24, 11370-11377. [CrossRef]

74. Chandra Hembram, K.; Prabha, S.; Chandra, R.; Ahmed, B.; Nimesh, S. Advances in Preparation and Characterization of Chitosan Nanoparticles for Therapeutics. Artif. Cells Nanomed. Biotechnol. 2016, 44, 305-314. [CrossRef]

75. Naskar, S.; Sharma, S.; Kuotsu, K. Chitosan-Based Nanoparticles: An Overview of Biomedical Applications and Its Preparation. J. Drug Deliv. Sci. Technol. 2019, 49, 66-81. [CrossRef]

76. Orellano, M.S.; Longo, G.S.; Porporatto, C.; Correa, N.M.; Falcone, R.D. Role of Micellar Interface in the Synthesis of Chitosan Nanoparticles Formulated by Reverse Micellar Method. Colloids Surf. A Physicochem. Eng. Asp. 2020, 599, 124876. [CrossRef]

77. El-Shabouri, M.H. Positively Charged Nanoparticles for Improving the Oral Bioavailability of Cyclosporin-A. Int. J. Pharm. 2002, 249, 101-108. [CrossRef] 
78. Kumar, S.; Dilbaghi, N.; Saharan, R.; Bhanjana, G. Nanotechnology as Emerging Tool for Enhancing Solubility of Poorly Water-Soluble Drugs. Bionanoscience 2012, 2, 227-250. [CrossRef]

79. Anu Bhushani, J.; Anandharamakrishnan, C. Electrospinning and Electrospraying Techniques: Potential Food Based Applications. Trends Food Sci. Technol. 2014, 38, 21-33. [CrossRef]

80. Yilmaz, M.T.; Yilmaz, A.; Akman, P.K.; Bozkurt, F.; Dertli, E.; Basahel, A.; Al-Sasi, B.; Taylan, O.; Sagdic, O. Electrospraying Method for Fabrication of Essential Oil Loaded-Chitosan Nanoparticle Delivery Systems Characterized by Molecular, Thermal, Morphological and Antifungal Properties. Innov. Food Sci. Emerg. Technol. 2019, 52, 166-178. [CrossRef]

81. Jalvo, B.; Faraldos, M.; Bahamonde, A.; Rosal, R. Antibacterial Surfaces Prepared by Electrospray Coating of Photocatalytic Nanoparticles. Chem. Eng. J. 2018, 334, 1108-1118. [CrossRef]

82. Pawar, A.; Thakkar, S.; Misra, M. A Bird's Eye View of Nanoparticles Prepared by Electrospraying: Advancements in Drug Delivery Field. J. Control. Release 2018, 286, 179-200. [CrossRef] [PubMed]

83. Zhang, S.; Kawakami, K. One-Step Preparation of Chitosan Solid Nanoparticles by Electrospray Deposition. Int. J. Pharm. 2010, 397, 211-217. [CrossRef] [PubMed]

84. Abyadeh, M.; Sadroddiny, E.; Ebrahimi, A.; Esmaeili, F.; Landi, F.S.; Amani, A. Electrosprayed Chitosan Nanoparticles: Facile and Efficient Approach for Bacterial Transformation. Int. Nano Lett. 2017, 7, 291-295. [CrossRef]

85. Abyadeh, M.; Aghajani, M.; Gohari Mahmoudabad, A.; Amani, A. Preparation and Optimization of Chitosan/PDNA Nanoparticles Using Electrospray. Proc. Natl. Acad. Sci. India Sect. B Biol. Sci. 2019, 89, 931-937. [CrossRef]

86. Wang, Y.; Zhang, R.; Qin, W.; Dai, J.; Zhang, Q.; Lee, K.J.; Liu, Y. Physicochemical Properties of Gelatin Films Containing Tea Polyphenol-Loaded Chitosan Nanoparticles Generated by Electrospray. Mater. Des. 2020, 185, 108277. [CrossRef]

87. Tapia-Hernández, J.A.; Torres-Chávez, P.I.; Ramírez-Wong, B.; Rascón-Chu, A.; Plascencia-Jatomea, M.; Barreras-Urbina, C.G.; Rangel-Vázquez, N.A.; Rodríguez-Félix, F. Micro- and Nanoparticles by Electrospray: Advances and Applications in Foods. J. Agric. Food Chem. 2015, 63, 4699-4707. [CrossRef]

88. Hu, Q.; Luo, Y. Recent Advances of Polysaccharide-Based Nanoparticles for Oral Insulin Delivery. Int. J. Biol. Macromol. 2018, 120, 775-782. [CrossRef]

89. Tavernini, L.; Ottone, C.; Illanes, A.; Wilson, L. Entrapment of Enzyme Aggregates in Chitosan Beads for Aroma Release in White Wines. Int. J. Biol. Macromol. 2020, 154, 1082-1090. [CrossRef]

90. Bugnicourt, L.; Ladavière, C. Interests of Chitosan Nanoparticles Ionically Cross-Linked with Tripolyphosphate for Biomedical Applications. Prog. Polym. Sci. 2016, 60, 1-17. [CrossRef]

91. Fernando, I.P.S.; Lee, W.W.; Han, E.J.; Ahn, G. Alginate-Based Nanomaterials: Fabrication Techniques, Properties, and Applications. Chem. Eng. J. 2019, 391, 123823. [CrossRef]

92. Quiñones, J.P.; Peniche, H.; Peniche, C. Chitosan Based Self-Assembled Nanoparticles in Drug Delivery. Polymers 2018, 10, 235. [CrossRef] [PubMed]

93. Mukhopadhyay, P.; Chakraborty, S.; Bhattacharya, S.; Mishra, R.; Kundu, P.P. PH-Sensitive Chitosan/Alginate Core-Shell Nanoparticles for Efficient and Safe Oral Insulin Delivery. Int. J. Biol. Macromol. 2015, 72, 640-648. [CrossRef]

94. Bhattacharyya, A.; Mukherjee, D.; Mishra, R.; Kundu, P.P. Preparation of Polyurethane-Alginate/Chitosan Core Shell Nanoparticles for the Purpose of Oral Insulin Delivery. Eur. Polym. J. 2017, 92, 294-313. [CrossRef]

95. Chen, T.; Li, S.; Zhu, W.; Liang, Z.; Zeng, Q. Self-Assembly PH-Sensitive Chitosan/Alginate Coated Polyelectrolyte Complexes for Oral Delivery of Insulin. J. Microencapsul. 2019, 36, 96-107. [CrossRef] [PubMed]

96. Pereira De Sousa, I.; Moser, T.; Steiner, C.; Fichtl, B.; Bernkop-Schnürch, A. Insulin Loaded Mucus Permeating Nanoparticles: Addressing the Surface Characteristics as Feature to Improve Mucus Permeation. Int. J. Pharm. 2016, 500, 236-244. [CrossRef] [PubMed]

97. Wong, C.Y.; Al-Salami, H.; Dass, C.R. Formulation and Characterisation of Insulin-Loaded Chitosan Nanoparticles Capable of Inducing Glucose Uptake in Skeletal Muscle Cells in Vitro. J. Drug Deliv. Sci. Technol. 2020, 57, 101738. [CrossRef]

98. Erel, G.; Kotmakçı, M.; Akbaba, H.; Sözer Karadağlı, S.; Kantarcı, A.G. Nanoencapsulated Chitosan Nanoparticles in Emulsion-Based Oral Delivery System: In Vitro and in Vivo Evaluation of Insulin Loaded Formulation. J. Drug Deliv. Sci. Technol. 2016, 36, 161-167. [CrossRef] 
99. He, Z.; Santos, J.L.; Tian, H.; Huang, H.; Hu, Y.; Liu, L.; Leong, K.W.; Chen, Y.; Mao, H.-Q. Scalable Fabrication of Size-Controlled Chitosan Nanoparticles for Oral Delivery of Insulin. Biomaterials 2017, 130, 28-41. [CrossRef]

100. Wiessner, J.H.; Hwang, K.J. Binding of Insulin to the External Surface of Liposomes. Effect of Surface Curvature, Temperature, and Lipid Composition. BBA Biomembr. 1982, 689, 490-498. [CrossRef]

101. Al-Remawi, M.; Elsayed, A.; Maghrabi, I.; Hamaidi, M.; Jaber, N. Chitosan/Lecithin Liposomal Nanovesicles as an Oral Insulin Delivery System. Pharm. Dev. Technol. 2017, 22, 390-398. [CrossRef] [PubMed]

102. Sahoo, P.; Leong, K.H.; Nyamathulla, S.; Onuki, Y.; Takayama, K.; Chung, L.Y. Optimization of PH-Responsive Carboxymethylated Iota-Carrageenan/Chitosan Nanoparticles for Oral Insulin Delivery Using Response Surface Methodology. React. Funct. Polym. 2017, 119, 145-155. [CrossRef]

103. Qin, Y.; Li, P.; Guo, Z. Cationic Chitosan Derivatives as Potential Antifungals: A Review of Structural Optimization and Applications. Carbohydr. Polym. 2020, 236, 116002. [CrossRef] [PubMed]

104. Wang, W.; Meng, Q.; Li, Q.; Liu, J.; Zhou, M.; Jin, Z.; Zhao, K. Chitosan Derivatives and Their Application in Biomedicine. Int. J. Mol. Sci. 2020, 21, 487. [CrossRef] [PubMed]

105. Tsai, L.-C.; Chen, C.-H.; Lin, C.-W.; Ho, Y.-C.; Mi, F.-L. Development of Mutlifunctional Nanoparticles Self-Assembled from Trimethyl Chitosan and Fucoidan for Enhanced Oral Delivery of Insulin. Int. J. Biol. Macromol. 2019, 126, 141-150. [CrossRef] [PubMed]

106. Jafary Omid, N.; Bahari Javan, N.; Dehpour, A.-R.; Partoazar, A.; Rafiee Tehrani, M.; Dorkoosh, F. In-Vitro and in-Vivo Cytotoxicity and Efficacy Evaluation of Novel Glycyl-Glycine and Alanyl-Alanine Conjugates of Chitosan and Trimethyl Chitosan Nano-Particles as Carriers for Oral Insulin Delivery. Int. J. Pharm. 2018, 535, 293-307. [CrossRef]

107. Mourya, V.K.; Inamdar, N.N. Trimethyl Chitosan and Its Applications in Drug Delivery. J. Mater. Sci. Mater. Med. 2009, 20, 1057-1079. [CrossRef]

108. Liu, M.; Zhang, J.; Zhu, X.; Shan, W.; Li, L.; Zhong, J.; Zhang, Z.; Huang, Y. Efficient Mucus Permeation and Tight Junction Opening by Dissociable "Mucus-Inert" Agent Coated Trimethyl Chitosan Nanoparticles for Oral Insulin Delivery. J. Control. Release 2016, 222, 67-77. [CrossRef]

109. Sheng, J.; Han, L.; Qin, J.; Ru, G.; Li, R.; Wu, L.; Cui, D.; Yang, P.; He, Y.; Wang, J. N-Trimethyl Chitosan Chloride-Coated PLGA Nanoparticles Overcoming Multiple Barriers to Oral Insulin Absorption. ACS Appl. Mater. Interfaces 2015, 7, 15430-15441. [CrossRef]

110. Sheng, J.; He, H.; Han, L.; Qin, J.; Chen, S.; Ru, G.; Li, R.; Yang, P.; Wang, J.; Yang, V.C. Enhancing Insulin Oral Absorption by Using Mucoadhesive Nanoparticles Loaded with LMWP-Linked Insulin Conjugates. J. Control. Release 2016, 233, 181-190. [CrossRef]

111. Shariatinia, Z. Carboxymethyl Chitosan: Properties and Biomedical Applications. Int. J. Biol. Macromol. 2018, 120, 1406-1419. [CrossRef] [PubMed]

112. Wang, J.; Xu, M.; Cheng, X.; Kong, M.; Liu, Y.; Feng, C.; Chen, X. Positive/Negative Surface Charge of Chitosan Based Nanogels and Its Potential Influence on Oral Insulin Delivery. Carbohydr. Polym. 2015, 136, 867-874. [CrossRef] [PubMed]

113. Krauland, A.H.; Alonso, M.J. Chitosan/Cyclodextrin Nanoparticles as Macromolecular Drug Delivery System. Int. J. Pharm. 2007, 340, 134-142. [CrossRef] [PubMed]

114. Song, M.; Li, L.; Zhang, Y.; Chen, K.; Wang, H.; Gong, R. Carboxymethyl- $\beta$-Cyclodextrin Grafted Chitosan Nanoparticles as Oral Delivery Carrier of Protein Drugs. React. Funct. Polym. 2017, 117, 10-15. [CrossRef]

115. Song, M.; Wang, H.; Chen, K.; Zhang, S.; Yu, L.; Elshazly, E.H.; Ke, L.; Gong, R. Oral Insulin Delivery by Carboxymethyl- $\beta$-Cyclodextrin-Grafted Chitosan Nanoparticles for Improving Diabetic Treatment. Artif. Cells Nanomed. Biotechnol. 2018, 46 (Suppl. S3), S774-S782. [CrossRef]

116. Verma, A.; Sharma, S.; Gupta, P.K.; Singh, A.; Teja, B.V.; Dwivedi, P.; Gupta, G.K.; Trivedi, R.; Mishra, P.R. Vitamin B12 Functionalized Layer by Layer Calcium Phosphate Nanoparticles: A Mucoadhesive and PH Responsive Carrier for Improved Oral Delivery of Insulin. Acta Biomater. 2016, 31, 288-300. [CrossRef]

117. Wang, J.; Kong, M.; Zhou, Z.; Yan, D.; Yu, X.; Cheng, X.; Feng, C.; Liu, Y.; Chen, X. Mechanism of Surface Charge Triggered Intestinal Epithelial Tight Junction Opening upon Chitosan Nanoparticles for Insulin Oral Delivery. Carbohydr. Polym. 2017, 157, 596-602. [CrossRef]

118. Yu, S.; Xu, X.; Feng, J.; Liu, M.; Hu, K. Chitosan and Chitosan Coating Nanoparticles for the Treatment of Brain Disease. Int. J. Pharm. 2019, 560, 282-293. [CrossRef] 
119. Frank, L.A.; Onzi, G.R.; Morawski, A.S.; Pohlmann, A.R.; Guterres, S.S.; Contri, R.V. Chitosan as a Coating Material for Nanoparticles Intended for Biomedical Applications. React. Funct. Polym. 2020, 147, 104459. [CrossRef]

120. Lopes, M.; Shrestha, N.; Correia, A.; Shahbazi, M.A.; Sarmento, B.; Hirvonen, J.; Veiga, F.; Seiça, R.; Ribeiro, A.; Santos, H.A. Dual Chitosan/Albumin-Coated Alginate/Dextran Sulfate Nanoparticles for Enhanced Oral Delivery of Insulin. J. Control. Release 2016, 232, 29-41. [CrossRef]

121. He, H.; Lu, Y.; Qi, J.; Zhu, Q.; Chen, Z.; Wu, W. Adapting Liposomes for Oral Drug Delivery. Acta Pharm. Sin. B 2019, 9, 36-48. [CrossRef] [PubMed]

122. Shalaby, T.I.; El-Refaie, W.M. Bioadhesive Chitosan-Coated Cationic Nanoliposomes With Improved Insulin Encapsulation and Prolonged Oral Hypoglycemic Effect in Diabetic Mice. J. Pharm. Sci. 2018, 107, 2136-2143. [CrossRef] [PubMed]

123. Moghassemi, S.; Parnian, E.; Hakamivala, A.; Darzianiazizi, M.; Vardanjani, M.M.; Kashanian, S.; Larijani, B.; Omidfar, K. Uptake and Transport of Insulin across Intestinal Membrane Model Using Trimethyl Chitosan Coated Insulin Niosomes. Mater. Sci. Eng. C 2015, 46, 333-340. [CrossRef] [PubMed]

124. Fonte, P.; Andrade, F.; Araújo, F.; Andrade, C.; Das Neves, J.; Sarmento, B. Chitosan-Coated Solid Lipid Nanoparticles for Insulin Delivery. In Methods in Enzymology; Academic Press Inc.: Cambridge, MA, USA, 2012; Volume 508, pp. 295-314. [CrossRef]

Publisher's Note: MDPI stays neutral with regard to jurisdictional claims in published maps and institutional affiliations.

(C) 2020 by the authors. Licensee MDPI, Basel, Switzerland. This article is an open access article distributed under the terms and conditions of the Creative Commons Attribution (CC BY) license (http://creativecommons.org/licenses/by/4.0/). 